\title{
Dissecting Taylor Rules in a Structural VAR
}

\author{
Woon Gyu Choi and Yi Wen
}




\title{
IMF Working Paper
}

\author{
IMF Institute
}

\section{Dissecting Taylor Rules in a Structural VAR}

\author{
Prepared by Woon Gyu Choi and Yi Wen ${ }^{1}$ \\ Authorized for distribution by Ling Hui Tan
}

January 2010

\begin{abstract}
This Working Paper should not be reported as representing the views of the IMF.

The views expressed in this Working Paper are those of the author(s) and do not necessarily represent those of the IMF or IMF policy. Working Papers describe research in progress by the author(s) and are published to elicit comments and to further debate.
\end{abstract}

This paper uncovers Taylor rules from estimated monetary policy reactions using a structural VAR on U.S. data from 1959 to 2009. These Taylor rules reveal the dynamic nature of policy responses to different structural shocks. We find that U.S. monetary policy has been far more responsive over time to demand shocks than to supply shocks, and more aggressive toward inflation than output growth. Our estimated dynamic policy coefficients characterize the style of policy as a "bang-bang" control for the pre-1979 period and as a gradual control for the post-1979 period.

JEL Classification Numbers:C51; E52

Keywords: endogenous monetary policy, Taylor rule, structural VAR, spectral decomposition Author's E-Mail Address:wchoi@imf.org; yi.wen@stls.frb.org

\footnotetext{
${ }^{1}$ Woon Gyu Choi is a Senior Economist at the IMF Institute of the International Monetary Fund. Yi Wen is an Assistant Vice President at the Federal Reserve Bank of St. Louis. We thank Enrica Detragiache, Ling Hui Tan, and Nicoletta Batini for useful comments and suggestions and Tack Yun for helpful conversations.
} 


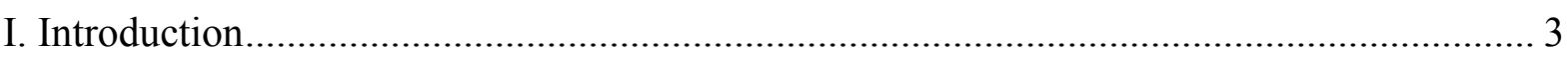

II. Econometric Framework for New Taylor Rules ...................................................... 5

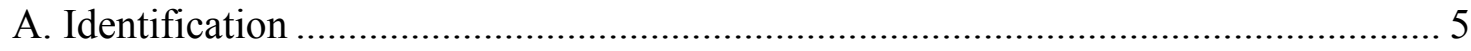

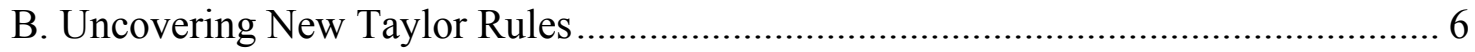

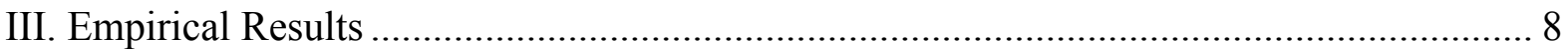

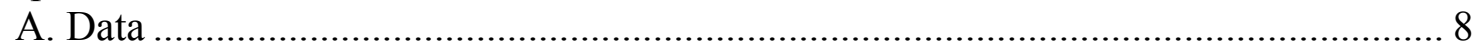

B. Impulse Responses and Historical Decompositions ......................................... 9

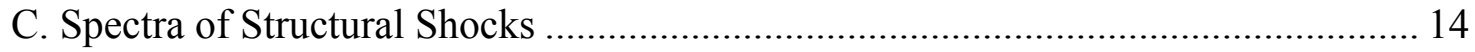

D. Uncovering and Dissecting Taylor Rules....................................................... 14

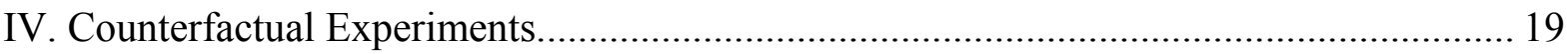

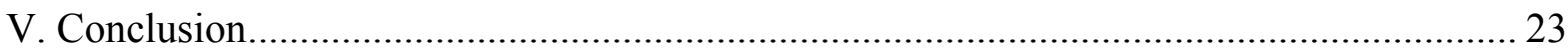

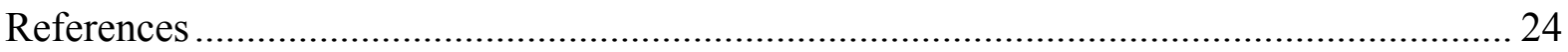

Tables

1. Spectral Decompositions of Volatility at Frequency Ranges ...................................... 15

2. Policy Coefficients in New Taylor Rules ............................................................. 16

3. Conventional Taylor Rules: GMM Estimation ............................................................... 19

Figures

1. Output Growth, Inflation, and Interest Rate .......................................................... 9

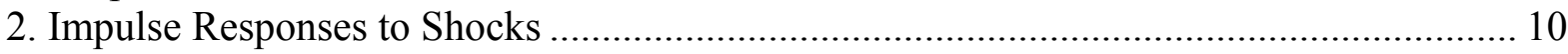

3. Historical Decompositions of Variables by Shocks and Distributions ............................ 12

4. Time Profiles of Taylor Rule Coefficients.................................................................. 17

5. Effects of the Contemporaneous Rule: Counterfactual Simulation .................................. 20

6. Impacts of the Contemporaneous Rule on Variance: Spectral Decomposition .............. 22 


\section{INTRODUCTION}

There is no doubt that monetary policy is largely endogenous, since it is the major means of fine-tuning the economy to reduce costly economic fluctuations driven by shocks. Given that it takes time for the impact of shocks to be manifested in macroeconomic aggregates such as output and inflation, the theoretical monetary literature suggests that optimal monetary policy should react directly to the causes of the fluctuations (that is, the shocks) rather than indirectly to the consequences of the fluctuations (that is, the movements in output and inflation). ${ }^{2}$

A challenge to researchers of monetary theory has always been how best to characterize and represent the endogenous aspect of optimal monetary policy. A large literature has suggested that good monetary policy can be represented by a simple interest rate policy rule proposed by Taylor (1993) - the Taylor rule. Most recent studies represent the Taylor rule as a relationship between the policy rate and some key macro variables (for example, the output gap and inflation). According to this conventional interpretation, the Federal Reserve ("Fed") should raise the federal funds rate in response to an increase in the output gap and inflation. A big advantage of the conventional Taylor rule is that it is a very intuitive and simple way of capturing the behavioral relationships between monetary policy and macro variables.

However, this representation and interpretation of the Taylor rule may not fully reconcile with the notion of optimal monetary policy because it not only ignores the fact that optimal control is a dynamic feedback and learning process, but also assumes away the policymakers' ability to react to the more fundamental causes behind the output gap and inflation. Policies that react only to the consequences rather than to the causes are clearly suboptimal.

The optimal-monetary-policy view advocates more discretion than the conventional interpretation of the Taylor rule. ${ }^{3}$ The conventional interpretation of the Taylor rule suggests that higher inflation should call for monetary tightening regardless of the sources of shocks. However, inflation pressure arises not only from the demand side (owing to, for example, credit expansions) but also from the supply side (owing to, for example, oil shocks). The desired policy responses to inflation stemming from a credit expansion will differ from those from an oil shock - the latter involves relative price changes as opposed to a uniform increase in the real

\footnotetext{
${ }^{2}$ In the theoretical literature on optimal monetary policy using dynamic stochastic general-equilibrium models, optimal monetary policy is designed with respect to specific shocks instead of to endogenous variables such as output or inflation (for example, Khan, King, and Wolman, 2003; Schmitt-Grohe and Uribe, 2004; and Benigno and Woodford, 2005). Considering the implementability condition, however, a number of studies have focused on a policy rule whereby policy variables are set as a function of a small number of easily observable macroeconomic indicators (Schmitt-Grohe and Uribe, 2007).

3 The more traditional monetary policy literature suggests that, in response to a positive demand shock, optimal policy is characterized as monetary tightening (Poole, 1970); and conversely in response to a positive productivity shock, monetary easing for output stability counteracts monetary tightening for price stability (Dotsey and King, 1983; and Canzoneri and others, 1983). More recently, Dotsey and Hornstein (2002) show that optimal interest rate policy requires lower interest rates in response to output increases driven by productivity shocks.
} 
interest rate. The same argument applies to the output gap. ${ }^{4}$ An important issue that has recently emerged is how policymakers should respond to supply-induced inflation stemming from rising commodity and food prices.

This paper characterizes endogenous monetary policy as a reaction function to structural shocks, as suggested by the optimal monetary policy literature. We estimate the reaction function of the Fed using structural VARs (SVARs) and map the structural response functions into a behavioral relationship between the policy rate and the shock-specific output and inflation movements. The uncovered behavioral relationship is analogous to the conventional Taylor rule, but with respect to decomposed individual structural shocks. We call these structural policy functions new Taylor rules. Along the lines of many studies that emphasize an important shift in monetary policy associated with Fed chairmanship, we estimate the new Taylor rules for two sub-samples: the pre-Volcker or pre-1979 (1960:Q1-79:Q2) period, encompassing the era of Martin, Burns, and Miller as Federal Reserve chairmen, and the post-1979 period (1979:Q309:Q1), including the terms of Volcker and Greenspan.

The new Taylor rules reveal richer information about the monetary policy stance than the conventional Taylor rule. First, the new Taylor rules show significant differences between the pre- and post-1979 periods. Consistent with earlier studies (Judd and Rudebusch, 1998; Clarida, Galí, and Gertler, 1999, 2000; Lubik and Schorfheide, 2004; Primiceri, 2005, 2006; and Boivin and Giannoni, 2006), ${ }^{5}$ monetary policy in the post-1979 period appears to have put more emphasis on fighting inflation than earlier. However, our results also indicate that the pre-1979 period was not associated with multiple equilibria as suggested, for example, by Clarida and others (2000). Second and more important, the degree of discretion and the style of the policy reaction functions between the two sub-periods differ starkly. The Fed appears to have become better at distinguishing demand and supply shocks and thus using discretion in response to different shocks in the post-1979 period than the pre-1979 period. In particular, the pre-1979 policy entailed an excessive initial response of interest rates to inflation and output growth, followed by a sharp decline in policy responses over longer horizons. This style of policy is the reminiscent of a "bang-bang" control. In contrast, the post-1979 policy entailed gradual interest rate responses to inflation and output growth over a time period of 10 quarters or longer. This style of policy reflects optimal control with a precautionary learning mechanism. ${ }^{6}$

\footnotetext{
${ }^{4}$ The conventional interpretation of the Taylor rule suggests that a higher output gap should call for monetary tightening. However, the optimal monetary policy literature would not necessarily recommend an equal amount of monetary contraction if the increased output gap is caused by an adverse supply shock to the trend component of output (for example, a natural disaster) rather than by a positive demand shock to the cyclical component of output.

${ }^{5}$ Many studies have stressed that monetary policymakers in the 1960s and 1970s were not as successful as those of the last two decades - the "policy mistakes" view. This view is compared with the "bad luck" view (the volatility of exogenous, non-policy shocks was higher) and the "lack of commitment" view (policymakers did not have incentives to keep inflation low) in explaining the high inflation in the 1960s and 1970s.

${ }^{6}$ There is a strand of the literature that focuses on policymakers' learning dynamics. For example, Primiceri (2006) suggests that the "Great Inflation" in the 1960s and 1970s was attributable to policymakers' bias on both the natural rate of unemployment and the persistence of inflation in the Phillips curve.
} 
This paper also uses counter-factual experiments to quantify the dynamic effect of endogenous monetary policy on inflation and output and the contribution of such a policy to stabilizing the economy. The traditional empirical literature on monetary policy effects identifies monetary policy changes as unanticipated shocks to the economy and conduct impulse response analysis and variance decomposition accordingly. The policy shocks identified in this way capture only the exogenous component of monetary policy. Hence this approach provides limited insight as to whether monetary policy is effective in reducing economic volatility. ${ }^{7}$ In contrast, we focus on the part of monetary policy that responds systematically to economic shocks. This endogenous aspect of monetary policy has not been fully investigated by the VAR literature. Notable exceptions are Bernanke, Gertler, and Watson (1997, 2004). This paper builds on Bernanke, Gertler, and Watson's work and takes a step further in this direction.

The paper proceeds as follows. Section II provides an econometric framework to develop new Taylor rules from an SVAR model. Section III describes the empirical results of the SVAR (with impulse responses, historical decompositions of variables, and spectral decompositions of volatility) and reports the estimated new Taylor rules, along with the conventional rules for comparison purposes. Section IV uses counterfactual simulations to evaluate the effects of contemporaneous endogenous policy. Section V concludes the paper.

\section{ECONOMETRIC FRAMEWORK FOR NEW TAYLOR RULES}

\section{A. Identification}

We consider a three-variable SVAR model to account for policy reactions to demand and supply shocks under a minimal structure. The variables included in the SVAR are output growth $(\Delta y)$, the rate of inflation $(\pi)$, and the nominal federal funds rate $(i) .{ }^{8}$ In line with the existing literature, we assume that the Fed has complete control of the funds rate as the policy rate. Hence movements in the funds rate reflect the intention of the monetary authority. ${ }^{9}$ All variables in the SVAR are assumed to be covariance stationary. ${ }^{10}$

The structural representation of the model is given by

$$
\mathbf{x}=\sum_{j=0}^{\infty} A_{j} \varepsilon_{t-j}=A(L) \boldsymbol{\varepsilon}
$$

\footnotetext{
${ }^{7}$ The exogenous aspect of monetary policy is not the focus of our paper since it has been widely studied in the literature (for example, Sims, 1982; Christiano and Eichenbaum, 1992; Galí, 1992; Leeper, Sims, and Zha, 1996; and Clarida, Galí, and Gertler, 2000).

${ }^{8}$ We use output growth instead of a measure of the output gap because we want to identify a permanent component in the output level from the SVAR analysis. This permanent component represents a stochastic long-run growth trend and can be viewed as the potential output.

${ }^{9}$ This by no means suggests that market forces do not play a role in moving the funds rate. However, the Fed has the absolute power to change the funds rate if it wants to intervene.

${ }^{10}$ For a robustness check, we find qualitatively the same results from an alternative model where inflation and the nominal interest rate are first-differenced.
} 
where $\mathbf{x} \equiv[\Delta y, \pi, i]^{\prime}$, and $\boldsymbol{\varepsilon}=\left[\varepsilon_{d}, \varepsilon_{s}, \varepsilon_{\mu}\right]^{\prime}$ is a vector of serially uncorrelated orthogonal disturbances to aggregate demand, aggregate supply and monetary policy, respectively. The Wold moving average representation of $\mathbf{x} \equiv[\Delta y, \pi, i]$ ' is given by

$$
\mathbf{x}=\sum_{j=0}^{\infty} C_{j} v_{t-j}=C(L) \mathbf{v}
$$

where $C_{0}=I, C(L)$ is assumed to be invertible, and $\mathbf{v}$ has the covariance matrix $E \mathbf{v v}{ }^{\prime}=\Sigma$. The following relationships hold between the two representations (1) and (2):

$$
\mathbf{v}=A_{0} \boldsymbol{\varepsilon} \text { and } A_{j}=C_{j} A_{0} \text { for all } j .
$$

where $A_{0}$ is invertible. To uncover the structural representation (1) from the data, we need to estimate (2) and use relationship (3) to uncover matrix $A_{0}$. By normalizing the variance of the structural shocks to unity, $\varepsilon \varepsilon^{\prime}=I$, we have $A_{0} A_{0}{ }^{\prime}=\Sigma$. Since $\Sigma$ is symmetric, three additional restrictions on the elements of $A_{0}$ are required to exactly identify $A_{0}$ and the three structural shocks, $\varepsilon=A_{0}^{-1} v$.

The following identifying restrictions are imposed to identify the three structural shocks (i.e., an aggregate supply shock, an aggregate demand shock and a monetary policy shock):

- R1: Demand shocks have no long-run effects on the level of output. Specifically, the $(1,1)$ element in the long-run matrix, $\sum_{j=0}^{\infty} A_{j}$, is zero.

- R2: Monetary policy shocks have no long-run effects on the level of output. Specifically, the $(1,3)$ element in the long-run matrix, $\sum_{j=0}^{\infty} A_{j}$, is zero.

- R3: Monetary policy shocks have no contemporaneous effects on output growth. Specifically, the $(1,3)$ element in the contemporaneous matrix $A_{0}$ is zero.

R1 and R2 imply that only supply shocks can have long-run effects on the level of output, consistent with a standard neoclassical growth model. R3 implies that a monetary policy shock can affect GDP only with a lag, a standard assumption in the VAR literature.

\section{B. Uncovering New Taylor Rules}

Structural representation (1) implies the following average reaction functions (impulse response) for the policy rate and economic fundamentals at arbitrary horizon of $N \geq 0$ periods:

$$
i_{t}=\frac{1}{N+1}\left(\sum_{j=0}^{N} a_{31}(j) \quad \sum_{j} a_{32}(j)\right)\left(\begin{array}{l}
\varepsilon_{d t} \\
\varepsilon_{s t}
\end{array}\right)+\frac{1}{N+1} \sum_{j} a_{33}(j) \varepsilon_{\mu t} \text {, }
$$




$$
\left(\begin{array}{c}
\Delta y_{t} \\
\pi_{t}
\end{array}\right)=\frac{1}{N+1}\left(\begin{array}{cc}
\sum_{j} a_{11}(j) & \sum_{j} a_{12}(j) \\
\sum_{j} a_{21}(j) & \sum_{j} a_{22}(j)
\end{array}\right)\left(\begin{array}{l}
\varepsilon_{d t} \\
\varepsilon_{s t}
\end{array}\right)+\frac{1}{N+1}\left(\begin{array}{c}
\sum_{j} a_{13}(j) \\
\sum_{j} a_{23}(j)
\end{array}\right) \varepsilon_{\mu t} .
$$

Using equation ( $4 b$ ) to express demand and supply shocks as functions of [ $\Delta y, \pi]$ by inversion and then substituting out $\left[\varepsilon_{d}, \varepsilon_{s}\right]$ in equation (4a) gives

$$
i_{t}=\left(\begin{array}{ll}
\sum_{j} a_{31}(j) & \sum_{j} a_{32}(j)
\end{array}\right)\left(\begin{array}{cc}
\sum_{j} a_{11}(j) & \sum_{j} a_{12}(j) \\
\sum_{j} a_{21}(j) & \sum_{j} a_{22}(j)
\end{array}\right)^{-1}\left(\begin{array}{c}
\Delta y_{t} \\
\pi_{t}
\end{array}\right)+\frac{1}{N+1} \sum_{j} \delta(j) \varepsilon_{\mu t} .
$$

Equation (5) is our new Taylor rule in its structural-behavioral form. This rule is analogous to the conventional Taylor rule adopted in the literature but is richer in structural information regarding the endogenous responses of the policy rate to structural shocks over time.

The new Taylor rule reveals information about the time profile of the policy reaction function to inflation and output growth over an arbitrary horizon $j=N$, after the economy is hit by exogenous shocks. It thus characterizes the behavioral style of the Fed. For example, a cautious policymaker would react to inflation and output growth in a piece-meal fashion by raising the interest rate gradually. In this case, the average reaction functions $\left[\partial i_{N} / \partial \pi, \partial i_{N} / \partial \Delta y\right]$ increase gradually over time. In contrast, an aggressive policymaker would react in a different manner by raising the interest rate sharply in the initial period. In this case, $\left[\partial i_{N} / \partial \pi, \partial i_{N} / \partial \Delta y\right]$ increase sharply in the impact period and decrease sharply in subsequent periods. The new Taylor rules thus enable us to investigate how the policymaker responds to inflation and output growth both in the short run and in the long run. For example, we can uncover the contemporaneous response of the policymaker to inflation and output growth in the impact period by $\operatorname{setting} N=0$ :

$$
\left.i_{t}\right|_{S R}=\left(\begin{array}{ll}
a_{31}(0) & a_{32}(0)
\end{array}\right)\left(\begin{array}{ll}
a_{11}(0) & a_{12}(0) \\
a_{21}(0) & a_{22}(0)
\end{array}\right)^{-1}\left(\begin{array}{c}
\Delta y_{t} \\
\pi_{t}
\end{array}\right)
$$

We can also uncover the long-run policy response to inflation and output growth by setting $N=\infty$ :

$$
\left.i_{t}\right|_{L R}=\left(\begin{array}{ll}
\sum_{j=0}^{\infty} a_{31}(j) & \sum_{j=0}^{\infty} a_{32}(j)
\end{array}\right)\left(\begin{array}{cc}
\sum_{j=0}^{\infty} a_{11}(j) & \sum_{j=0}^{\infty} a_{12}(j) \\
\sum_{j=0}^{\infty} a_{21}(j) & \sum_{j=0}^{\infty} a_{22}(j)
\end{array}\right)^{-1}\left(\begin{array}{c}
\Delta y_{t} \\
\pi_{t}
\end{array}\right) .
$$

In addition, we can decompose the policy reaction functions into partial responses to demand- and supply-induced movements in economic fundamentals. 
$\operatorname{Define}\left(\begin{array}{ll}b_{11}(N) & b_{12}(N) \\ b_{21}(N) & b_{22}(N)\end{array}\right)=\left(\begin{array}{ll}\sum_{j=0}^{N} a_{11}(j) & \sum_{j=0}^{N} a_{12}(j) \\ \sum_{j=0}^{N} a_{21}(j) & \sum_{j=0}^{N} a_{22}(j)\end{array}\right)^{-1}$. Then equation (5) implies the

following decomposition:

$$
\begin{aligned}
& i_{t}=\left(\begin{array}{ll}
\sum_{j=0}^{N} a_{31}(j) & \sum_{j=0}^{N} a_{32}(j)
\end{array}\right)\left(\begin{array}{ll}
b_{11}(N) & b_{12}(N) \\
b_{21}(N) & b_{22}(N)
\end{array}\right)\left(\begin{array}{c}
\Delta y_{t} \\
\pi_{t}
\end{array}\right)
\end{aligned}
$$

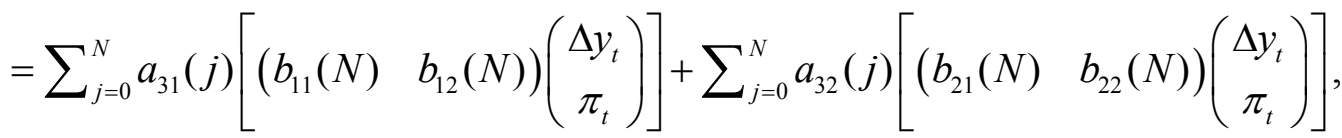

where the first component captures policy responses to demand-induced inflation and output growth, and the second component captures policy responses to supply-induced ones. We call the first component the demand-side Taylor rule and the second component the supply-side Taylor rule. These shock-specific rules can also be expressed in their long- and short-run forms by setting $N=0$ and $N=\infty$ respectively, as in equations (6) and (7).

In the existing literature, a measure of the output gap instead of output growth is typically used in the Taylor rule. In our framework, we can also uncover the Taylor rule coefficients with respect to a measure of the output gap. Define the output gap as $\hat{y}=y-y^{*}$, where $y$ is the log of actual output and $y^{*}$ is the log of potential output determined by long-run technology growth. Given that permanent changes in GDP can be interpreted as a long-run stochastic growth trend driven by permanent technology shocks (see Blanchard and Quah 1988), supply-induced movements in output growth can be the measure of $\Delta y^{*}$ and demand-induced movements in output growth can be the measure of $\Delta \hat{y}$. Integrating $\Delta \hat{y}$ over time gives the desired measure of the output gap. The Taylor rule coefficients with respect to this measure of the output gap can be uncovered from the estimated impulse response functions of $\Delta \hat{y}{ }^{11}$

\section{Empirical Results}

\section{A. Data}

We use quarterly U.S. time series data over the period 1959:Q1-2009:Q1. ${ }^{12}$ The quarterly rates of output growth and inflation in period $t$ are measured by $\Delta y_{t} \equiv \Delta \log \left(Y_{t}\right)$ and $\pi_{t} \equiv \Delta \log \left(P_{t}\right)$, respectively, where $Y_{t}$ is real GDP and $P_{t}$ is the GDP deflator (alternatively, the $\mathrm{CPI})$. The policy rate $\left(i_{t}\right)$ is measured by the federal funds rate.

\footnotetext{
${ }^{11}$ Another definition of the output gap characterizes potential output as a deterministic linear trend, $y^{*}=\gamma t$, where $\gamma$ is the mean growth rate of the economy. It is also straightforward in this case to uncover the Taylor rule coefficients with respect to the output gap from our estimated impulse response functions.

${ }^{12}$ We used the following data series, obtained from the website of the Federal Reserve Bank of St. Louis (FRED): GDP (nominal GDP), GDPC1 (real GDP), FEDFUNDS (effective federal funds rate, \%), and CPIAUCSL (consumer price index: all items).
} 
Figure 1. Output Growth, Inflation, and Interest Rate

Interest Rate
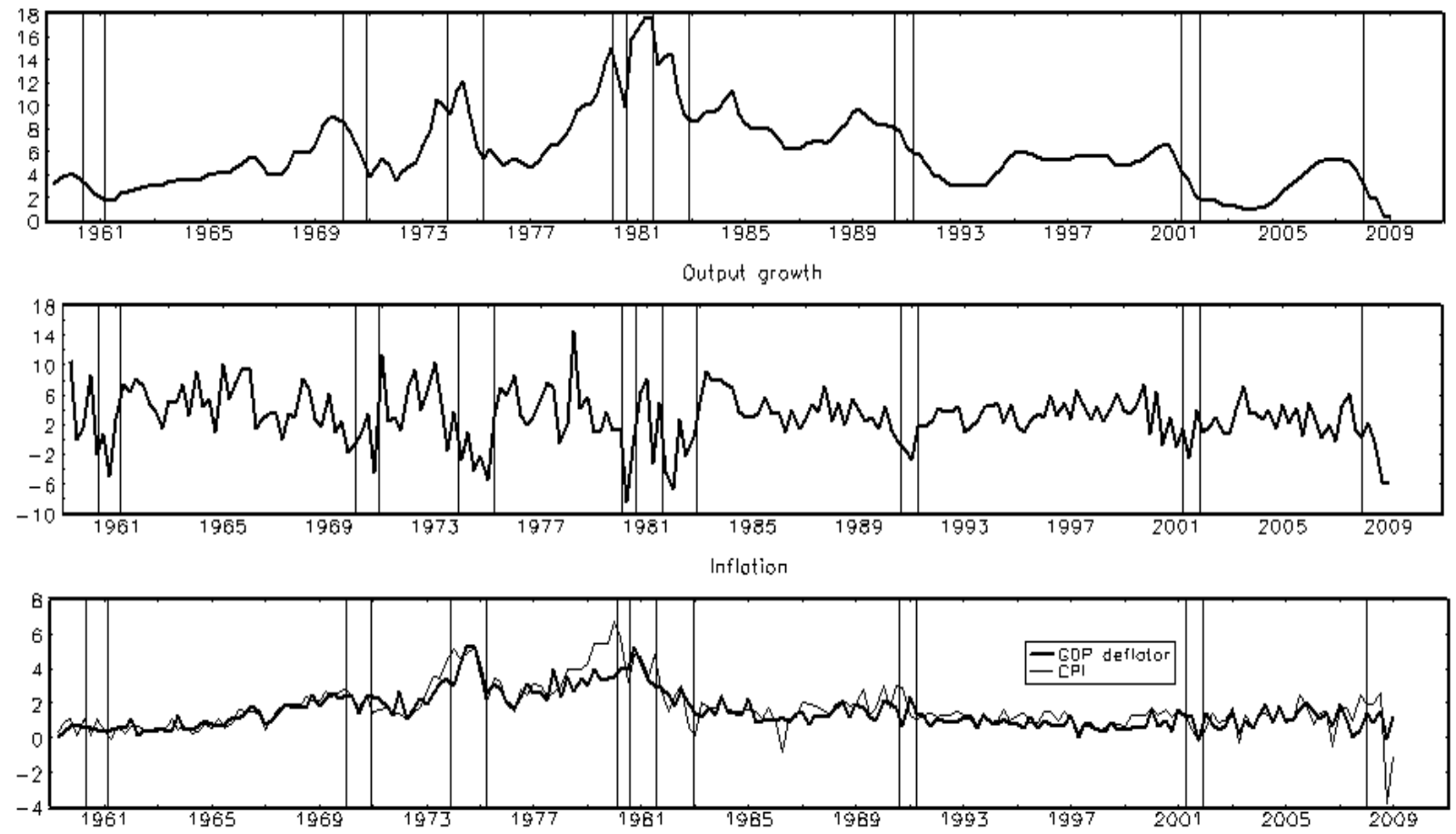

Notes: All rates for 1959:Q1-2009:Q1 are quarterly data in annualized percentage. Output growth and inflation, respectively, are measured by 400 times the log difference of real GDP and the price index (the GDP deflator or $\mathrm{CPI}$ ). The interest rate is the federal funds rate (annual percentage). Vertical lines denote NBER business cycle peaks and troughs.

Figure 1 displays the annualized quarterly interest rates, output growth, and inflation, along with NBER business cycle peaks and troughs. The (nominal) interest rate tended to move closely with inflation during much of the 1960s and 1970s when inflation was high and persistent, but this association was much weaker or nonexistent in other periods when inflation was relatively low and transitory (Choi, 2002). The interest rate rose in 1994-95 owing to the Fed's preemptive tightening but remained steady during 1996-98 despite higher output growth (Sinai, 2004). The interest rate declined after the 2001 recession and remained low before rising in 2005. During the financial turmoil of 2007-09, the interest rate fell to historically low levels, close to zero by end2008. Inflation was high and persistent during the 1970s, especially attributable to oil shocks. Volcker's anti-inflation policy kept inflation in check in 1982 and, thereafter, policy has consistently aimed at keeping inflation low. Around the 1973, 1979, and 2007 oil shocks, CPI inflation was followed by GDP deflator inflation, since CPI was more susceptible to oil price changes than the GDP deflator.

\section{B. IMPULSE RESPONSES AND HISTORICAL DECOMPOSITIONS}

We compute responses of the variables to one-unit structural shocks in SVARs for the preand post-1979 periods. We also report one-standard-error bands of responses based on 10,000 replications of bootstrapping. The estimated impulse responses are largely consistent with model restrictions and intuitive expectations implied by economic theory. 
Figure 2. Impulse Responses to Shocks

A. Pre-1979

Output Level
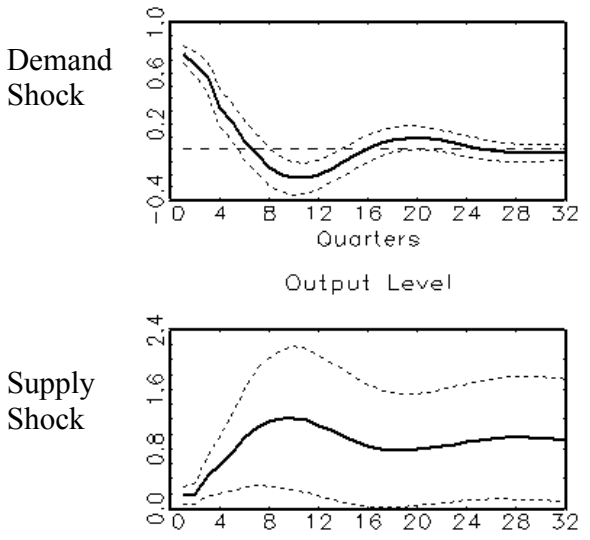

Gutput Level

Policy

Shock

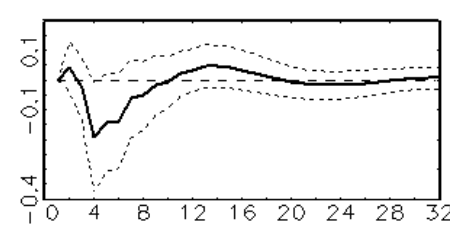

Output Level

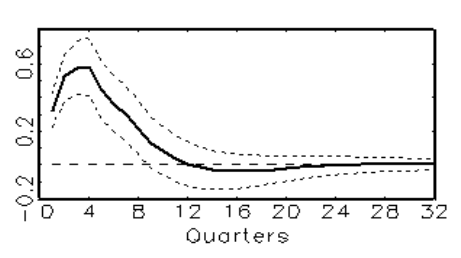

Output Level

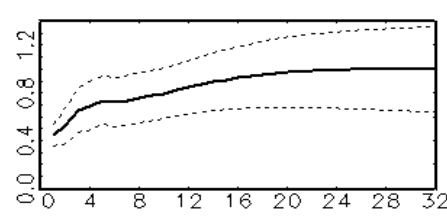

Output Level

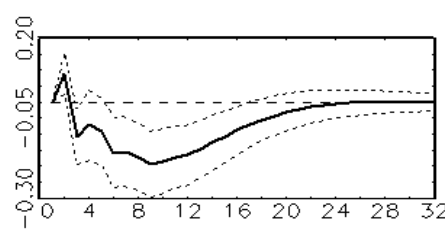

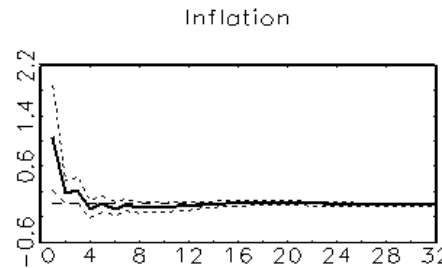

\section{B. Post-1979}

Inflotion

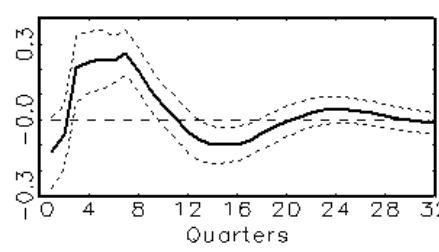

inflotion

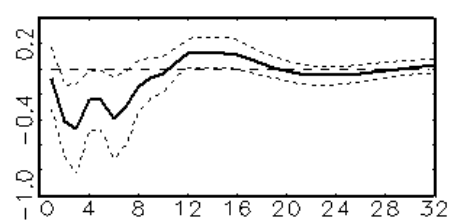

Inflation

Inflation

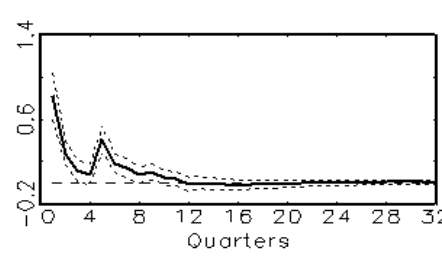

Inflotion

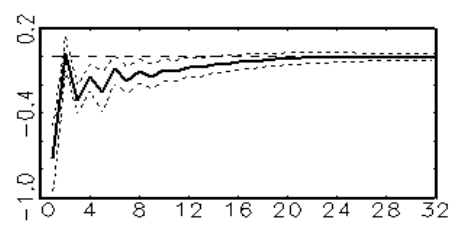

Inflation

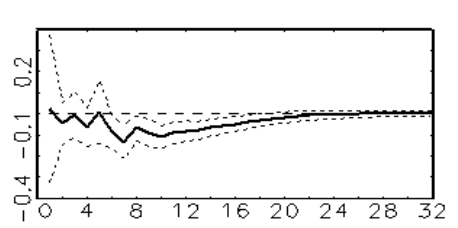

Interest Rotes

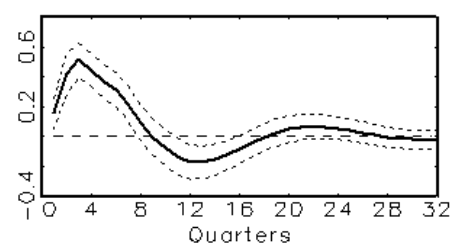

Interest Rotes

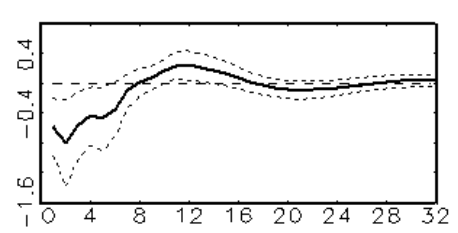

Interest Rotes

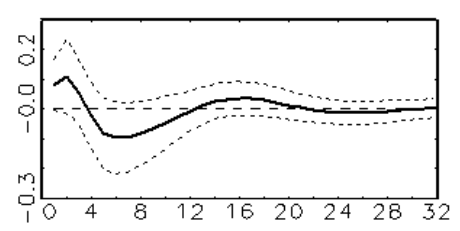

nterest Rates

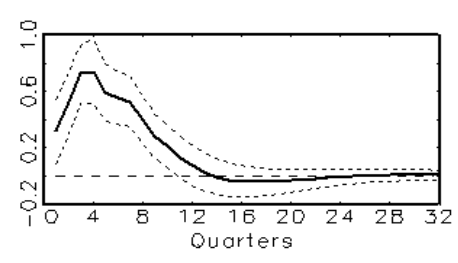

interest Rates

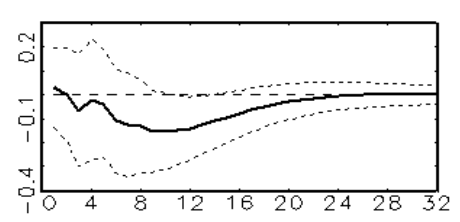

Interest Rotes

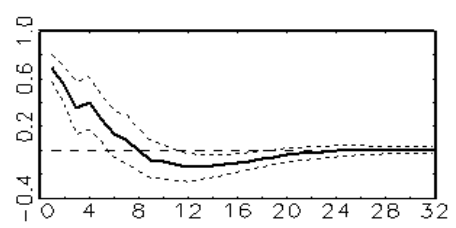

Notes: Impulse-response functions are depicted using the GDP deflator as the price index for the post-1979 period. The lag length $k=4$ is chosen for the SVAR model. Vertical scales show the log of output level multiplied by 100 , and inflation and interest rates in annualized percentage. Impulse responses (solid lines) are reported with onestandard-error bands (dotted lines) computed from 10,000 replications of bootstrapping. 
We depict the estimated impulse responses of the SVAR in Figure 2. Key differences between the sub-periods are threefold. First, the pattern of output and inflation responses to a demand shock differs across the two periods: a hump-shaped response is found for inflation in the pre-1979 period and for output growth in the post-1979 period. Second, a policy shock has a larger and more persistent impact on interest rates in the post-1979 period (when the conduct of monetary policy involved changes in the policy rate), compared to the earlier period (when monetary aggregates were the focus of monetary policy). Third, inflation falls persistently upon the policy shock for the post-1979 period but does not fall first three quarters in the pre-1979 period, consistent with Boivin and Giannoni (2006). Positive responses of inflation to the positive policy rate shock - much less persistent than the case of "price puzzles" of 3 or 4 years - can be explained as follows. Barth and Ramey (2001) suggest that prices could rise following tighter policy if monetary policy operates not only through demand effects but also through supply or cost effects. ${ }^{13}$ Higher interest rates and financing costs following tighter policy lead to higher marginal production costs - a "cost-channel effect." Also, reduced demand for real balances with higher interest rates may require an immediate jump in inflation for money market clearing when money supply is exogenous (Barro, 1997, chapter 5) —a "real-balance-channel effect." In the pre-1979 period, the cost-channel and real-balance-channel effects appear to outweigh demand effects. Conversely in the post-79 period, the so-called price puzzle disappears. This possibly reflects that negative demand effects of monetary policy on inflation dominate positive effects through the cost and real-balance channels, the latter channel being muted when money supply becomes largely endogenous under interest rate policy.

We now focus on the SVAR responses for the post-1979 period (panel B), given the above comparisons of responses between the sub-periods. First, a positive, one-unit shock to aggregate demand (row 1) has a positive hump-shaped impact on output over three years. The demand shock is associated with upward pressure on inflation: the inflation response reaches a peak immediately. The interest rate response to the demand shock exhibits persistence with a hump shape, reaching a peak in the fourth quarter. The peak may be associated with the culmination of tighter policy after the initial pressure from increased output and inflation. Second, a positive shock to aggregate supply (row 2) leads to a higher output level in the long run and puts downward pressure on inflation - in accordance with neoclassical models: it increases GDP by 0.5 percentage point on impact and by 1.5 percentage points in 8 years. The shock has a persistent negative effect on inflation and is accompanied by a persistent decline in the interest rate (an accommodative policy), as downward pressure on interest rates from the substantially reduced inflation outweighs upward pressure from the increased output. Lastly, a positive policy shock (row 3) entails persistence, in accordance with the Fed's interest rate smoothing (Choi, 1999; and Clarida and others, 1999, 2000). Output declines with a brief lag and converges rather slowly to its original level. The policy rate hike leads to lower inflation over time, perhaps partly reflecting a signaling effect of policy rate changes.

Figure 3 shows how each of structural shocks contributed to historical movements in a key variable in the system, along with their distributions. Panel A suggests that cyclical fluctuations in output growth are more attributable to supply shocks than to other shocks. Demand shocks

\footnotetext{
${ }^{13}$ Giordani (2004) shows that introducing the output gap and capacity utilization in VARs reduces the price puzzle but does not eliminate it for periods including pre-1979 samples.
} 
Figure 3. Historical Decompositions of Variables by Shocks and Distributions

A. Output growth
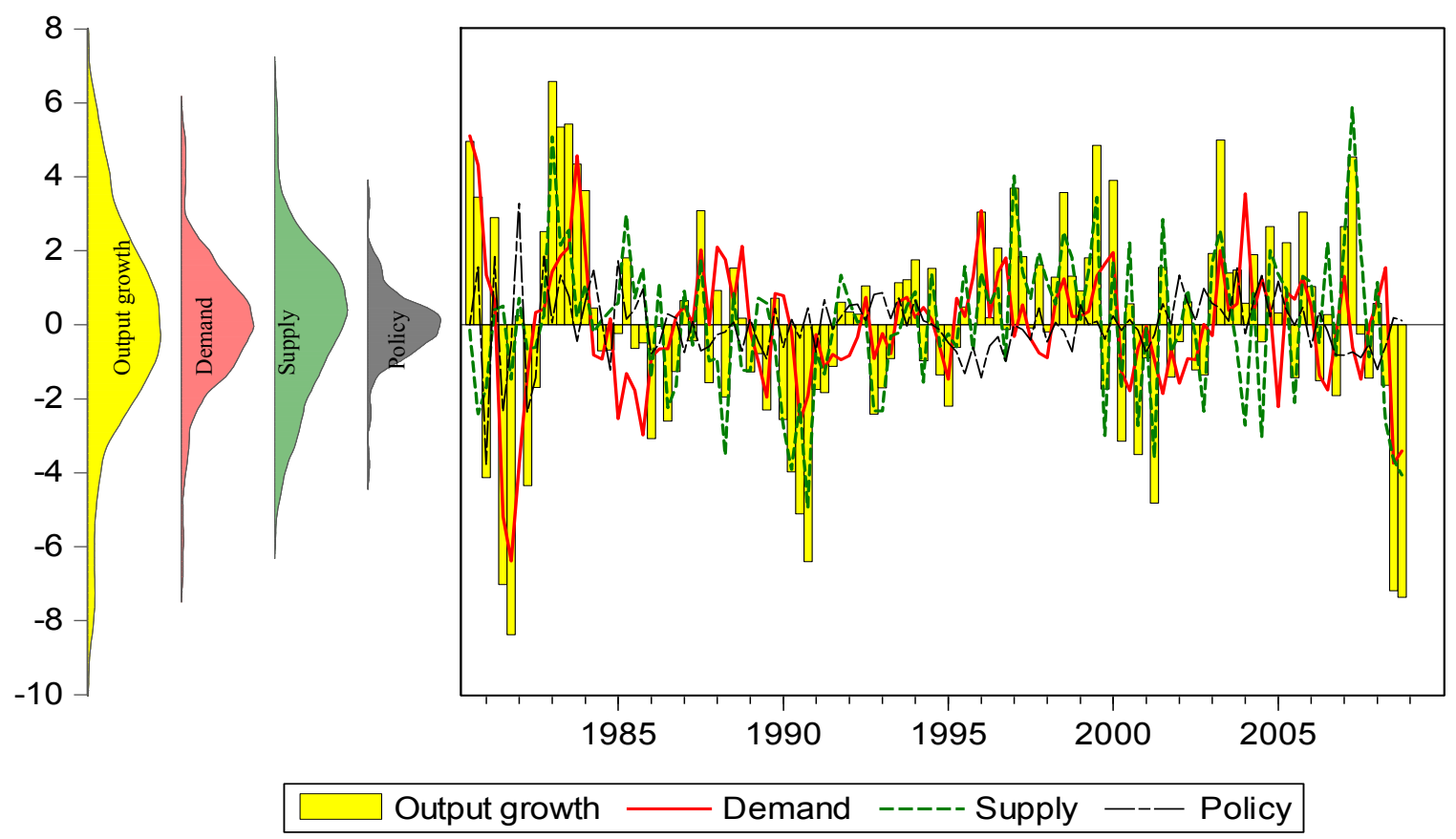

B. Inflation
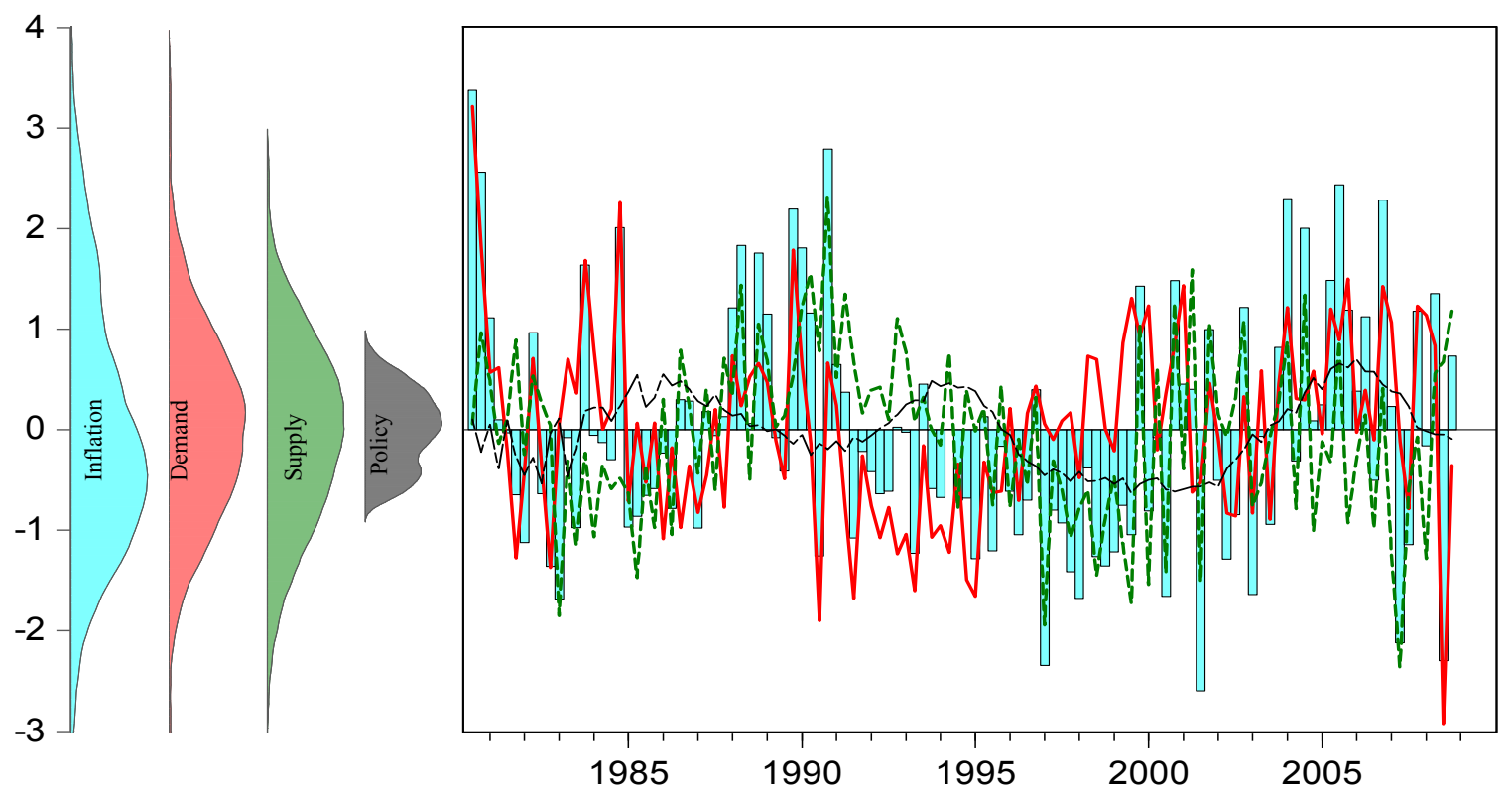

Inflation — Demand ----- Supply --- Policy 


\section{Interest Rates}

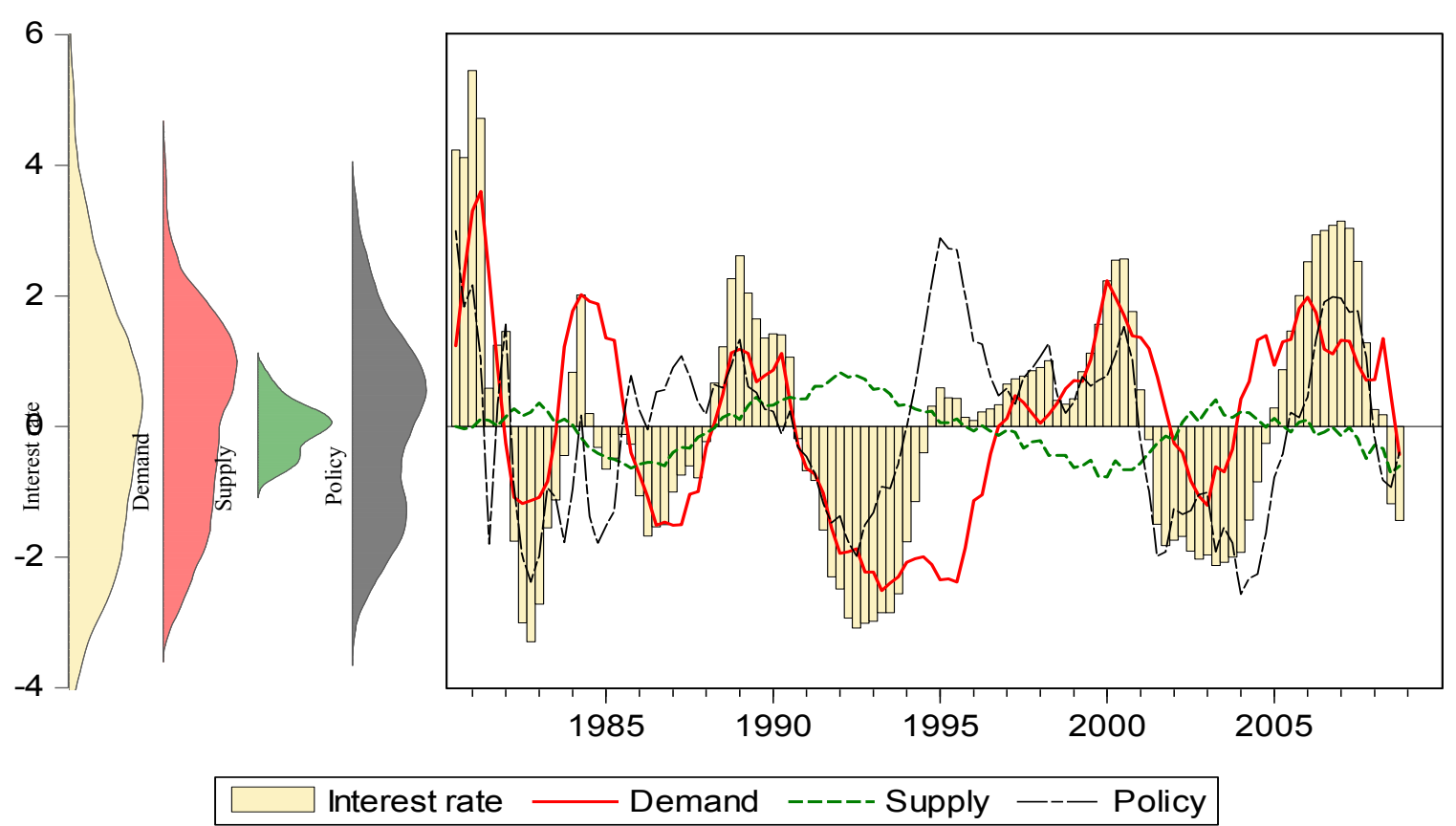

Notes: This figure depicts historical decompositions of output growth, inflation, and interest rates by contributing structural shocks, expressed in deviations from the historical mean, for the post-79 period. It also shows distributions of variables and contributing shocks. The colored bars in panels depict the annualized quarterly growth rate in output growth, inflation, and interest rates. The various lines in each panel show the estimated contributions of the various shocks (demand shocks in solid red lines; supply shocks in dotted green lines; and policy shocks in dash-dotted black lines).

clearly contributed to the onset of all recessions. Supply shocks contributed to most recessions except for the 1982 recession. Policy shocks tended to reduce output growth before the onset of recessions, implying the Fed's policy tightening around the peak of business cycles.

Panel B suggests that inflation variability is attributable equally to demand and supply shocks. The contribution of supply shocks to inflation has an inverse image to that of demand shocks to output growth, consistent with neoclassical theory-a positive supply shock induces downward pressure on inflation by increasing output growth from the supply side. Negative demand shocks exerted downward pressure on inflation in recessions. Adverse supply shocks increased inflationary pressures during the 1980, 1990, and 2008 recessions: ${ }^{14}$ in the 2008 recession, rising energy and material costs induced positive pressure on inflation, while predominating downward inflationary pressures arose from negative demand shocks. Policy shocks contributed positively to inflationary swings after the mid-1990s, in contrast with most of the earlier periods. In particular, the positive contribution of policy shocks to inflation during

\footnotetext{
${ }^{14}$ The contribution of supply shocks to output growth and inflation is substantially lower for the 1980s and 1990s, which may be attributable partly to the reduced variance of supply shocks (Favero and Rovelli, 2003; and Cecchetti and others, 2004).
} 
2003-05 may be partly attributable to "fear of deflation," which led to monetary easing and asset price booms before the financial crisis. The observation that policy shocks were somewhat aligned with endogenous monetary policy means that, around the turning point in inflation, the Fed reacted more than what would have been expected by a systematic feedback rule.

Panel C suggests that interest rate variability is more attributable to demand shocks than to supply shocks. Demand shocks drove interest rates whereas supply shocks often affected interest rates in opposite directions - but both shocks pulled down interest rates during the 2007-09 financial crisis. Policy shocks also contributed substantially to interest variability, while offsetting demand shocks during the second half of the 1980s and around the mid-1990s.

\section{Spectra of Structural Shocks}

Using spectral analysis, we assess the contribution of structural shocks identified from the SVARs to the volatility of output, inflation, and interest rates in the frequency domain. Table 1 reports the shock contribution to volatility at different frequency ranges. Shock contributions differ between the pre- and post-1979 periods. In particular, inflation volatility at high frequencies is attributable more to policy shocks than to other shocks in the pre-1979 period but mainly attributable to demand shocks in the later period. Output volatility at high frequencies is driven by demand shocks in the pre-1979 period but by supply shocks in the later period.

For the pre-1979 period (panel A), supply shocks have a dominant contribution to output volatility at low frequencies ( 93 percent), while demand shocks do at the business cycle (63 percent) and high frequencies (88 percent). Inflation volatility is mostly attributable to policy shocks at high frequencies ( 83 percent) and to supply shocks at other frequencies. Interest rate volatility in all frequency ranges is dominated by supply shocks (over 60 percent).

For the post-1979 period (panel B), supply shocks have a dominant contribution to output volatility at high frequencies ( 51 percent) as well as at low frequencies ( 75 percent), while demand shocks do at the business cycle (over 60 percent). Inflation volatility in all frequency ranges is mainly attributable to demand shocks and little to policy shocks. Interest rate volatility is driven by policy shocks at high frequencies ( 81 percent) and by demand shocks at the business cycle and low frequencies (60-75 percent), but very little by supply shocks, reflecting smooth and substantive policy responses to demand shocks.

\section{UNCOVERING AND DISSECTING TAYLOR RULES}

We next estimate the new Taylor rules to evaluate the stance of U.S. monetary policy for two sub-samples associated with Fed chairmanship: the pre-Volcker or pre-1979 (1960:Q1-79:Q2) and post-1979 period (1979:Q3-09:Q1).

The new Taylor rule in equation (5) can be expressed as:

$$
i_{t}=\beta_{\pi} \pi_{t}+\beta_{\Delta y} \Delta y_{t}+\delta(L) \varepsilon_{i t} .
$$

We obtain the new Taylor rule from the estimated SVAR when inflation is measured in the GDP 
Table 1. Spectral Decompositions of Volatility at Frequency Ranges

\begin{tabular}{|c|c|c|c|c|c|}
\hline \multirow{2}{*}{ Shock } & \multirow{2}{*}{ Variable } & \multicolumn{4}{|c|}{ Frequency Range } \\
\hline & & All & High & $\begin{array}{c}\text { Business } \\
\text { Cycle }\end{array}$ & Low \\
\hline \multicolumn{6}{|l|}{ A. Pre-1979 Period } \\
\hline \multirow{3}{*}{ Demand shock } & Output & 0.72 & 0.88 & 0.63 & 0.07 \\
\hline & Inflation & 0.16 & 0.04 & 0.22 & 0.18 \\
\hline & Interest rate & 0.33 & 0.12 & 0.34 & 0.36 \\
\hline \multirow[t]{3}{*}{ Supply shock } & Output & 0.23 & 0.06 & 0.33 & 0.93 \\
\hline & Inflation & 0.36 & 0.12 & 0.42 & 0.61 \\
\hline & Interest rate & 0.65 & 0.86 & 0.63 & 0.63 \\
\hline \multirow[t]{3}{*}{ Policy shock } & Output & 0.05 & 0.06 & 0.04 & 0.00 \\
\hline & Inflation & 0.48 & 0.83 & 0.36 & 0.21 \\
\hline & Interest rate & 0.02 & 0.02 & 0.02 & 0.00 \\
\hline \multicolumn{6}{|c|}{ B. Post-1979 Period } \\
\hline \multirow[t]{3}{*}{ Demand shock } & Output & 0.41 & 0.26 & 0.61 & 0.20 \\
\hline & Inflation & 0.53 & 0.53 & 0.64 & 0.46 \\
\hline & Interest rate & 0.64 & 0.17 & 0.60 & 0.75 \\
\hline \multirow[t]{3}{*}{ Supply shock } & Output & 0.47 & 0.51 & 0.36 & 0.75 \\
\hline & Inflation & 0.42 & 0.45 & 0.32 & 0.44 \\
\hline & Interest rate & 0.05 & 0.02 & 0.02 & 0.07 \\
\hline \multirow[t]{3}{*}{ Policy shock } & Output & 0.12 & 0.23 & 0.03 & 0.05 \\
\hline & Inflation & 0.05 & 0.01 & 0.04 & 0.10 \\
\hline & Interest rate & 0.31 & 0.81 & 0.38 & 0.18 \\
\hline
\end{tabular}

Notes: The statistics are from the spectral analysis of impulse responses in the SVAR for the pre-1979 period (1960:Q2-1979:Q2) and the post-1979 period (1979:Q3-2009:Q1). The sum of contribution by all types of shocks to the volatility of a variable equals 1 at a given range of frequency: high (2-6 quarters), business cycle (6-32), or low (32-10 $0^{5}$. (See also Figure 6 for spectral density functions under the historical scenario.)

deflator (Table 2, panel A). We also report standard errors (in parentheses) of the estimated coefficients calculated from 10,000 replications of bootstrapping. The new long-run Taylor rule (abstracting from the exogenous policy shocks) is given by:

$$
\begin{aligned}
& \text { Pre-1979: }\left.\quad i\right|_{L R}=\underset{(0.62)}{1.93} \pi+\underset{(0.33)}{0.32} \Delta y \text {, } \\
& \text { Post-1979: }\left.\quad i\right|_{L R}=\underset{(0.68)}{2.23 \pi} \pi+\underset{(0.38)}{0.97} \Delta y .
\end{aligned}
$$

Monetary policy for both periods was anti-inflationary and ensured equilibrium determinacy because the long-run inflation coefficient is larger than one. The small and insignificant coefficient of output growth for the pre-1979 period suggests that the Fed was quite lenient with respect to output pressure. The new Taylor rule also reveals that the Fed has been more aggressive in stabilizing output growth in the post-1979 period. 
Table 2. Policy Coefficients in New Taylor Rules

\begin{tabular}{|c|c|c|c|c|c|c|}
\hline \multirow[t]{2}{*}{ Period and Rule } & \multicolumn{2}{|c|}{ Aggregate } & \multicolumn{2}{|c|}{ Demand Shock } & \multicolumn{2}{|c|}{ Supply Shock } \\
\hline & $\beta_{\pi}$ & $\beta_{\Delta y}$ & $\beta_{\pi}$ & $\beta_{\Delta y}$ & $\beta_{\pi}$ & $\beta_{\Delta y}$ \\
\hline \multicolumn{7}{|c|}{ A. GDP Deflator as the price measure } \\
\hline \multicolumn{7}{|c|}{ Pre-1979 } \\
\hline Long-run & $1.93(0.62)$ & $0.32(0.33)$ & $1.93(0.62)$ & $0.98(0.36)$ & $0.00(0.00)$ & $-0.65(0.13)$ \\
\hline Contemporaneous & $12.96(4.87)$ & $0.61(0.24)$ & $0.72(0.40)$ & $0.08(0.40)$ & $12.24(4.41)$ & $0.53(0.22)$ \\
\hline \multicolumn{7}{|l|}{ Post-1979 } \\
\hline Long-run & $2.23(0.68)$ & $0.97(0.38)$ & $2.23(0.68)$ & $1.40(0.56)$ & $0.00(0.00)$ & $-0.43(0.36)$ \\
\hline Contemporaneous & $0.22(0.20)$ & $0.11(0.04)$ & $0.23(0.14)$ & $0.10(0.06)$ & $-0.02(0.08)$ & $0.01(0.04)$ \\
\hline \multicolumn{7}{|c|}{ B. CPI as the price measure } \\
\hline \multicolumn{7}{|c|}{ Pre-1979 } \\
\hline Long-run & $1.05(0.32)$ & $0.68(0.27)$ & $1.05(0.32)$ & $0.68(0.27)$ & $0.00(0.00)$ & $-0.62(0.16)$ \\
\hline Contemporaneous & $1.08(0.88)$ & $0.02(0.05)$ & $0.06(0.11)$ & $0.04(0.03)$ & $1.02(0.80)$ & $-0.03(0.05)$ \\
\hline \multicolumn{7}{|l|}{ Post-1979 } \\
\hline Long-run & $1.80(0.28)$ & $0.72(0.23)$ & $1.80(0.28)$ & $1.40(0.60)$ & $0.00(0.00)$ & $-0.68(0.59)$ \\
\hline Contemporaneous & $0.25(0.10)$ & $0.09(0.04)$ & $0.15(0.09)$ & $0.15(0.04)$ & $0.11(0.10)$ & $-0.06(0.04)$ \\
\hline
\end{tabular}

Notes: This table reports the policy coefficients of new Taylor rules for the pre-1979 (1960:Q2-1979:Q2) and post-1979 (1979:Q3-2009:Q1) periods, using the GDP deflator (panel A) or CPI (panel B) as the price variable. The quarterly rates of interest, output growth, and inflation in period $t$ are measured by the federal funds rate/400, $\Delta y_{t} \equiv \Delta \log \left(Y_{t}\right)$, and $\pi_{t} \equiv \Delta \log \left(P_{t}\right)$, respectively, where $Y_{t}$ is real GDP and $P_{t}$ is the price index. The new Taylor rules are constructed by applying equations (6)-(8) to the estimated SVAR model. Figures in brackets are standard errors of each parameter estimate obtained from 10,000 replications of bootstrapping.

The long-run Taylor rules dissected by the source of shocks are estimated as:

$$
\begin{aligned}
& \text { Demand-Induced } \\
& \text { Pre-1979: }\left.\quad i\right|_{L R}=\underset{(0.62)}{1.93} \pi+\underset{(0.36)}{0.98} \Delta y \\
& \text { Post-1979: }\left.\quad i\right|_{L R}=\underset{(0.68)}{2.23} \pi+\underset{(0.56)}{1.40} \Delta y \\
& \begin{array}{c}
\text { Supply-Induced } \\
\left.i\right|_{L R}=\underset{(0.00)}{0.00 \pi-} \begin{array}{c}
0.65 \\
(0.13)
\end{array} \Delta y, \\
\left.i\right|_{L R}=\underset{(0.00)}{0.00 \pi-\underset{(0.36)}{0.43} \Delta y .}
\end{array}
\end{aligned}
$$

The results suggest that the Fed is able to differentiate demand shocks from supply shocks and takes different policy stances depending on the source of shocks. Monetary policy in both periods was anti-inflationary under demand shocks but non-responsive to inflation under supply shocks. Also, the Fed in both periods raised interest rates against faster output growth under demand shocks but eased interest rates for faster output growth under supply shocks.

The short- and longer-run behavior of the new Taylor rule suggests a shift from a bang-bang to a gradual control in the dynamic pattern of policy responses, as shown in Table 2 . The pre1979 policy reflected overreactions to inflation in the short run - the contemporaneous inflation coefficient based on the GDP deflator (12.96) is much greater than the long-run coefficient (1.93). During this period, the policy response to demand-induced output growth was small and 
Figure 4. Time Profiles of Taylor Rule Coefficients

A. Pre-1979 Period

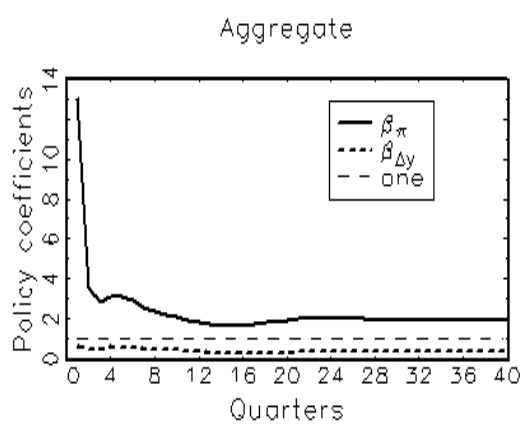

Aggregate

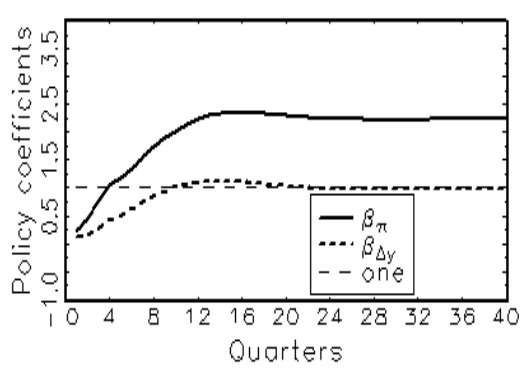

Demand

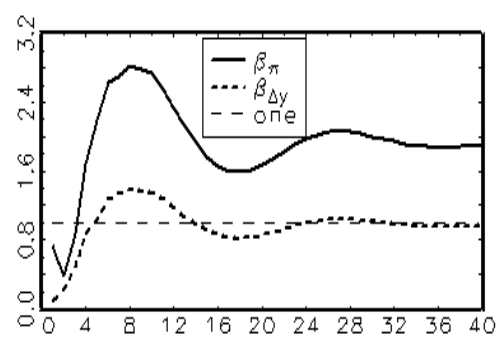

B. Post-1979 Period

Demond

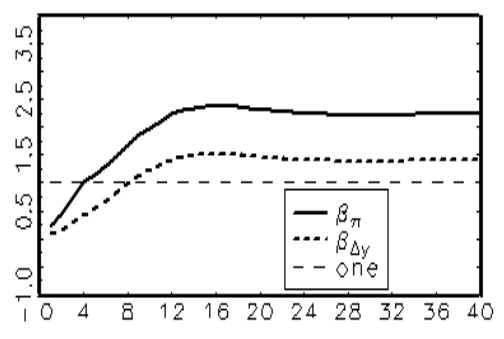

Supply

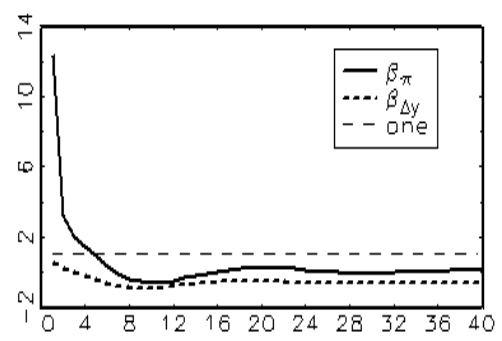

Supply

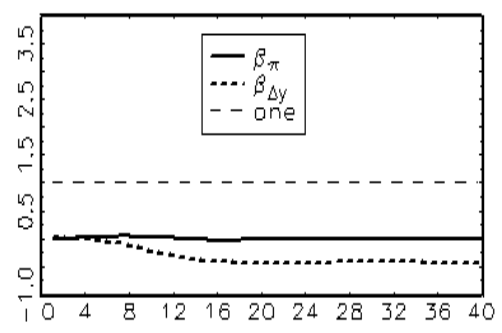

Notes: Policy coefficients in the new Taylor rule are uncovered from the SVAR with the GDP deflator for each indicated sample period. For all periods, the lag length is chosen at $k=4$. In each row, policy coefficients on inflation $\left(\beta_{\Delta \pi}\right)$, and output growth $\left(\beta_{\Delta y}\right)$ from all sources (first panel) are decomposed into those from demand shocks (second panel) and supply shocks (third panel).

insignificant contemporaneously but significantly positive in the long run. During the post-1979 period, however, the intensity of policy responses was small contemporaneously and gradually rose over time. In both periods, monetary policy was less aggressive toward output fluctuations than toward inflation in the short run and the long run.

Figure 4 complements the above findings by depicting the dynamic transitions of policy coefficients in the new Taylor rule using the GDP deflator as the price measure. Aggregate policy coefficients (column 1) show a stark difference between the pre- and post-1979 periods. The salient feature of the pre-1979 period is the short-run overshooting of the interest rate response to inflation, as shown by the dynamics of $\beta_{\pi}$. This finding suggests that the Fed, in the short run, raised the rate sharply with higher inflation, especially stemming from supply shocks, and then took corrective changes with its reduced interest rate sensitivity to inflation. In contrast, the post-1979 policy entails a gradual transition in dynamic policy reactions. Columns 2 and 3 depict dynamic policy coefficients decomposed into demand- and supply-induced ones on output growth and inflation using equation (8). Upon demand shocks, the Fed raised the funds rate increasingly over time to stabilize output and inflation. Conversely upon supply shocks, except for a strong initial response against supply-induced inflation, the Fed tended to accommodate pressures on output and inflation over time, as implied by the low or even negative long-run values of $\beta_{\pi}$ and $\beta_{\Delta y}$ for all sub-periods. 
Our results overall are robust to an alternative price index. As shown in Table 2 panel B, when the CPI is used, the estimated Taylor rule coefficients under our structural analysis are similar, except that the contemporaneous coefficient of CPI inflation for the pre-1979 period is followed by a further sharp increase in $\beta_{\pi}$ with a short lag.

For comparison purposes, we estimate a conventional dynamic Taylor rule with interest rate smoothing, along the lines of Rudebusch $(1995,2002)$ and Söderlind and others (2005).

$$
\Delta i_{t}=(1-\rho)\left(\beta_{\pi} \pi_{t}+\beta_{\Delta y} \Delta y_{t}-i_{t-1}\right)+\xi_{t},
$$

which is drawn from its original form: $i_{t}=(1-\rho)\left(\beta_{\pi} \pi_{t}+\beta_{\Delta y} \Delta y_{t}\right)+\rho i_{t-1}+\xi_{t}$, where $\rho$ is an "interest rate smoothing" parameter $(0<\rho<1)$, representing a monotone, geometric response of interest rates to inflation and output growth. This specification allows for contemporaneous responses of interest rates to inflation and output growth, consistent with the SVAR model restrictions. To deal with the endogeneity of regressors, we estimate the rule by the generalized method of moments (GMM), using lagged values of inflation, output growth, interest rates, and the Livingston survey forecast values of inflation and output growth as instruments. ${ }^{15}$

Table 3 summarizes the estimated conventional Taylor rules. First, all policy coefficient estimates are significantly positive. For the pre-1979 period, a relatively smaller weight is placed on inflation than output growth, and the long-run inflation coefficient is less than unity, not supporting long-run stabilization of inflation. Conversely for the post-1979 period, a relatively higher weight is placed on inflation than on output growth, and the long-run inflation coefficient is larger than unity (about 2 or larger). Second, the estimated $\rho$ is in the range of $0.7-0.9-$ implying that policy responses gradually increase over time, irrespective of the source of shocks - and indicates stronger interest rate inertia for the post-1979 period than the earlier period. Third, for the post-1979 period, relatively low $R^{2}$ may reflect low variability in interest rates. $R^{2}$ is as low as 0.18 with CPI for the post-1979 period, substantially owing to large innovations in CPI inflation during the 2008 recession. Fourth, the errors have no serious firstorder serial correlation problem as suggested by Durbin-Watson $(D W)$ statistics, while we find correlograms of residuals indicative of some higher-order serial correlations. Lastly, Hansen's $J$ test results weakly support the null hypothesis of instrument validity (with $p$-values $\geq 0.05$ ).

Unlike conventional Taylor rules, the new Taylor rules feature very different, flexible dynamics in policy coefficients. For the pre-1979 period, the new Taylor rules entail a short-run overreaction of interest rates to (especially supply-induced) inflation, which requires subsequent corrective policy reactions, in contrast to the dynamic policy response implied by conventional rules. For the post-1979 period, the new Taylor rule better squares with the conventional rule in terms of interest rate smoothing as well as contemporaneous and long-run coefficients. For this

\footnotetext{
${ }^{15}$ Semi-annual forecast data for real GDP growth and CPI inflation from the Livingston Survey are converted into quarterly data. Pre-1979 regressions use the industrial production forecast as a proxy for the output forecast available only from 1971 (correlation between the two variables is 0.93 for 1971:Q1-2009:Q1).
} 
Table 3. Conventional Taylor Rules: GMM Estimation

\begin{tabular}{|c|c|c|c|c|c|c|}
\hline \multirow[t]{2}{*}{ Period and Rule } & \multicolumn{3}{|c|}{ Parameters } & \multicolumn{3}{|c|}{ Statistics } \\
\hline & $\beta_{\pi}$ & $\beta_{\Delta y}$ & $\rho$ & $R^{2}$ & $D W$ & $J$-Test \\
\hline \multicolumn{7}{|c|}{ A. GDP Deflator as the price measure } \\
\hline \multicolumn{7}{|c|}{ Pre-1979 } \\
\hline Long-run & $0.68(0.12)$ & $1.39(0.45)$ & \multirow{2}{*}{$0.73(0.08)$} & \multirow{2}{*}{0.43} & \multirow{2}{*}{1.73} & \multirow{2}{*}{0.05} \\
\hline Contemporaneous & $0.18(0.06)$ & $0.37(0.06)$ & & & & \\
\hline \multicolumn{7}{|l|}{ Post-1979 } \\
\hline Long-run & $3.01(0.60)$ & $1.16(0.39)$ & \multirow{2}{*}{$0.88(0.04)$} & \multirow{2}{*}{0.28} & \multirow{2}{*}{2.04} & \multirow{2}{*}{0.05} \\
\hline Contemporaneous & $0.36(0.08)$ & $0.14(0.03)$ & & & & \\
\hline \multicolumn{7}{|c|}{ B. CPI as the price measure } \\
\hline \multicolumn{7}{|c|}{ Pre-1979 } \\
\hline Long-run & $0.65(0.12)$ & $0.98(0.41)$ & \multirow{2}{*}{$0.77(0.07)$} & \multirow{2}{*}{0.43} & \multirow{2}{*}{1.72} & \multirow{2}{*}{0.13} \\
\hline Contemporaneous & $0.15(0.05)$ & $0.22(0.06)$ & & & & \\
\hline \multicolumn{7}{|l|}{ Post-1979 } \\
\hline Long-run & $2.30(0.42)$ & $1.96(0.83)$ & \multirow{2}{*}{$0.90(0.03)$} & \multirow{2}{*}{0.18} & \multirow{2}{*}{2.12} & \multirow{2}{*}{0.06} \\
\hline Contemporaneous & $0.23(0.05)$ & $0.19(0.04)$ & & & & \\
\hline
\end{tabular}

Notes: This table summarizes the conventional Taylor rules estimated by GMM for the pre-1979 (1960:Q21979:Q2) and post-1979 (1979:Q3-2009:Q1) periods. The policy rate is the funds rate (annual percentage). Output growth and inflation, respectively, are measured by 400 times the log difference of real GDP and the price index. Estimates of contemporaneous coefficients are obtained, using the delta method, from the GMM estimators of longrun coefficients and $\rho$. Instruments are two lags of inflation and output growth, and current and one-period lagged values of expected inflation and output growth, both based on the Livingston survey data. Standard errors (in parentheses) are the heteroscedasticity and autocorrelation robust errors using the Bartlett kernel and the Andrews bandwidth. The $J$-test statistic is the $p$-value of Hansen's test for instrument validity.

period, since the short-run inflation coefficient is far below unity, an increase in inflation leads to a temporary decline in the real interest rate, increasing aggregate demand and raising subsequent inflationary pressure. For both periods, however, as implied by the long-run coefficient on inflation greater than unity, the increase in inflation calls for higher real interest rates through monetary policy over the long run, dampening aggregate demand and stabilizing inflation. ${ }^{16}$

\section{COUNTERFACTUAL EXPERIMENTS}

We conduct counterfactual simulations to evaluate the effectiveness of endogenous monetary policy. Counterfactual policy simulations, in general, would be subject to the Lucas (1976) critique because model parameters may vary with policy shifts (Hamilton and Herrera, 2004; and Bernanke, Gertler, and Watson, 2004). Bernanke, Gertler, and Watson deal with the Lucas

\footnotetext{
${ }^{16}$ Our finding is consistent with Chowdhury and Schabert's (2008) finding from the "money supply lens" approach - which looks at that money supply responses to inflation and the output gap - that the Fed policy was sufficiently reactive to inflation so as to ensure equilibrium determinacy during the pre-1979 period.
} 
Figure 5. Effects of the Contemporaneous Rule: Counterfactual Simulation

A. Pre-1979 Period
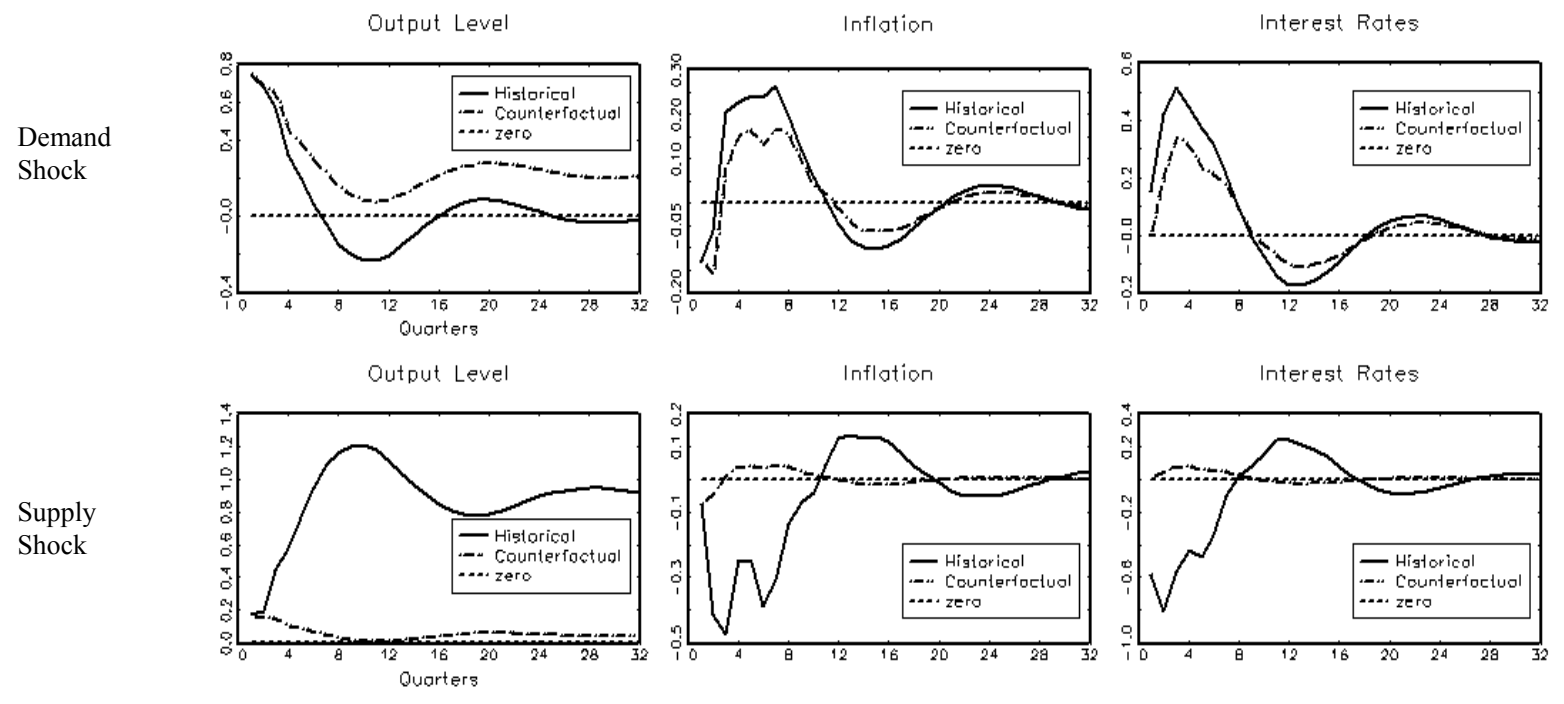

B. Post-1979 Period
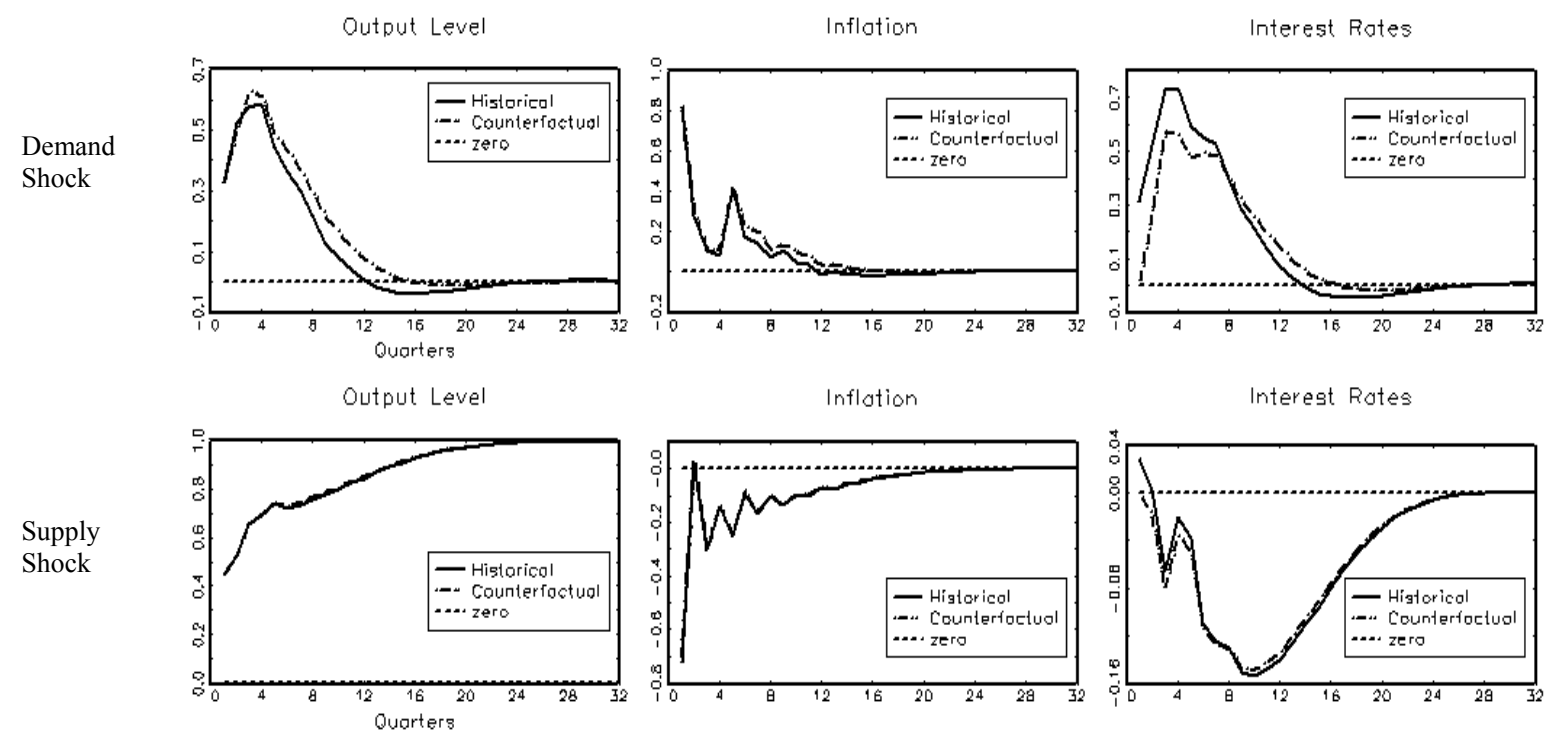

Notes: Responses under the historical rule (solid line) and those under the counterfactual scenario (dash-dot line) are from the SVAR with the GDP deflator. Vertical scales show the log of output level multiplied by 100, and inflation and interest rates in annualized percentage.

critique in a VAR analysis by examining transitory, rather than permanent, deviations from the observed policy rule. Specifically, they examine the effect of a shock on the economy when the endogenous policy response is "shut off" - that is, when the funds rate is held fixed for the initial four quarters, after which its behavior is governed by historical policy rule. ${ }^{17}$ They find that the

${ }^{17}$ In contrast, the Sims and Zha (1998) experiment is to shut down "indefinitely" the policy response that would otherwise be implied by the VAR estimates. In this case, people are "repeatedly surprised" by the failure of the policy response to non-policy shocks, as Bernanke, Gertler, and Watson (1997) point out. 
effects of an oil price shock on output are reduced considerably when the endogenous response of the funds rate is shut off, suggesting that the endogenous policy conducted in history exacerbated rather than reduced the impact of the shock.

Our counterfactual analysis is in line with, but less vulnerable to the Lucas critique than that of Bernanke, Gertler, and Watson's approach. We shut off only the contemporaneous response of the funds rate to exogenous shocks by setting contemporaneous policy coefficients at zero. Such a one-period change in the policy rule should barely affect the structure of the economy since it would take time for people to learn about the change in policy reaction functions. ${ }^{18} \mathrm{We}$ compare impulse responses under the "historical rule" that allows for contemporaneous policy with those under the "counterfactual scenario" that imposes no contemporaneous policy.

Figure 5 depicts variable responses to demand shocks and supply shocks under different periods. Comparing the historical rule with the counterfactual scenario, we find sharp differences in policy impacts between the pre- and post-1979 periods (Figure 3). First, for the pre-1979 period (panel A), contemporaneous policy has substantial impacts on output and inflation. A contemporaneous policy response to output and inflation pressures set off by a positive demand shock results in a lower output level, ${ }^{19}$ and renders inflation and interest rates higher in the short run and more volatile over time, compared to the counterfactual scenario. Upon a supply shock, the historical policy rule entails, despite increased output pressure set off by the shock, decreases in the policy rate with reduced inflation, boosting the level of output. In contrast, under the counterfactual scenario, no contemporaneous policy results in little changes in the output level and inflation over time. Second, for the post-1979 period (panel B), contemporaneous policy has no substantive impacts owing to contemporaneous policy coefficients in the historical rule. Nonetheless, when the policy rate increases contemporaneously in response to output and inflation pressures set off by the demand shock, output is somewhat lowered over the medium term, compared to the counterfactual case.

Contemporaneous monetary policy has different impacts on economic stability between the pre- and post-1979 periods. Figure 6 shows the impacts of counterfactual monetary policy on the variance (power spectrum) of output growth, inflation, and interest rates in the frequency domain. The peak in inflation volatility shifts from the business cycle frequency to lower frequency after 1979, implying a smoother inflation in the business cycle but a greater swing in the long run, consistent with earlier studies (King and Lin, 2005; and Ireland, 2007). This may suggest a trade off between short-run and long-run inflation stability.

Turning to the details of the graph, for the pre-1979 period (panel A), output volatility at the business cycle and low frequencies is attributable substantially to contemporaneous policy actions, especially to supply shocks around the peak of quarter 20. Inflation and interest rate volatilities are also substantially attributable to contemporaneous policy reactions to demand shocks and, with a greater extent, to supply shocks. For the post-1979 period (panel B),

\footnotetext{
18 Leeper and Zha (2003) show that a modest policy change has a small impact on agents' beliefs about policy regime and thus induces no change in the behavior of agents.

${ }^{19}$ In the counterfactual scenario, the demand shock can have a permanent effect on output because imposing zero contemporaneous coefficients invalidates restriction R1 when those coefficients are non-zero in the historical rule.
} 
Figure 6. Impacts of the Contemporaneous Rule on Variance: Spectral Decomposition

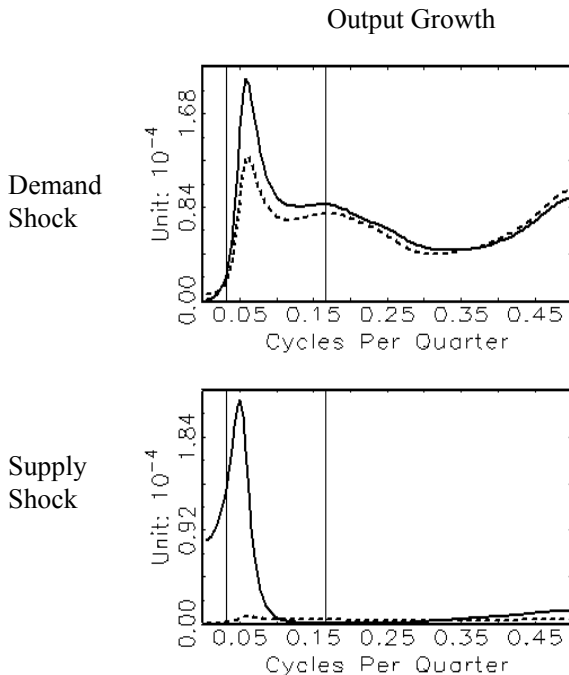

Output Growth
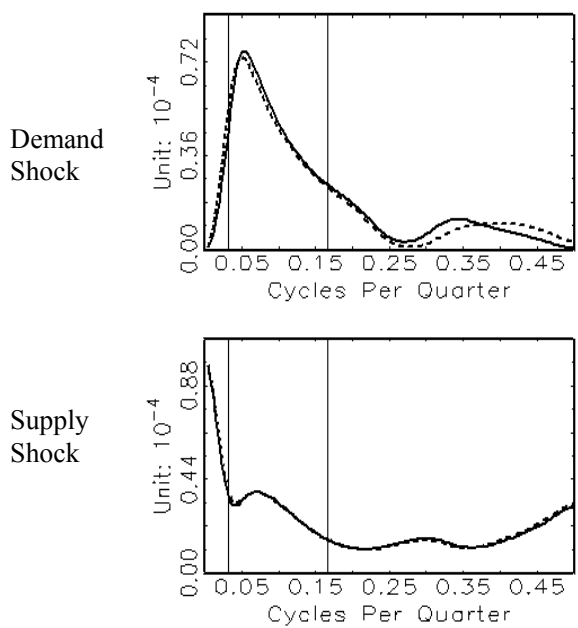

A. Pre-1979 Period
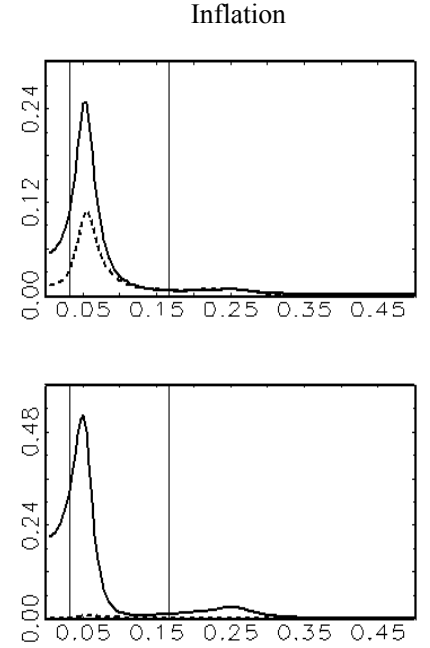

B. Post-1979 Period

Inflation
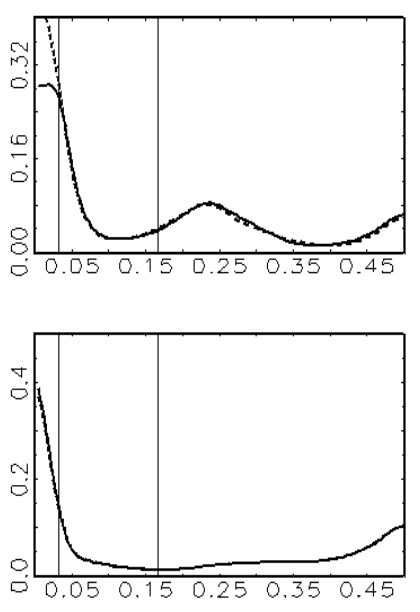

Interest Rates
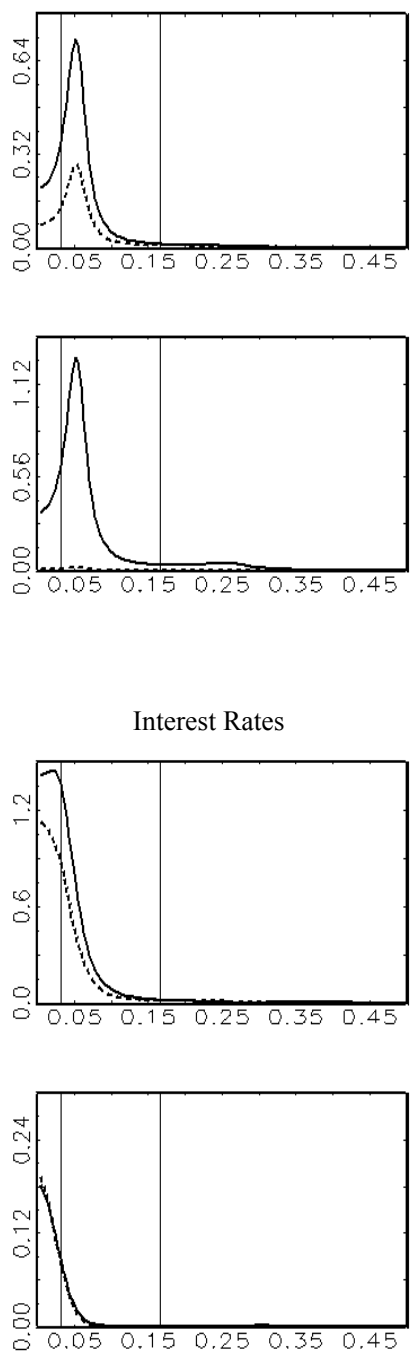

Notes: The decomposed components of the historical scenario (solid lines) and those of the counterfactual scenario (dotted lines) are depicted. The impacts of policy shocks on volatilities, which are the same in the historical and the counterfactual scenario, are not depicted. Vertical scales are based on the differenced log levels of output and prices and the level of interest rates (annual percentage/400). Cycles per quarter equal to frequency/2 $\pi$, where the frequency ranges from 0 to $\pi$. (The period of the cycle is the inverse of cycles per quarter.)

volatilities are much less attributable to contemporaneous policy actions than earlier. Notably, contemporaneous policy actions result in higher output and inflation volatilities during the pre1979 period, whereas they reduce somewhat inflation volatility but affect little output volatility during the later period. Hence, the shift in the Fed's monetary policy from a bang-bang control to a gradual one is conducive to macroeconomic stability. This finding is consistent with the view that the Fed has conducted systematic monetary policy more effectively since 1980 (Clarida and others, 2000; Primiceri, 2005, 2006; and Boivin and Giannoni, 2006). 


\section{Conclusion}

This paper examines endogenous monetary policy from the structural perspective that optimal policy for macroeconomic stability ought to respond directly to the source of shocks rather than indirectly to the consequences of shocks for inflation and output. Our analysis brings the empirical VAR literature into closer touch with the theoretical literature on optimal monetary policy in dynamic stochastic general-equilibrium models, in which monetary policy is optimal only with respect to specific shocks. We uncover behavioral relationships between the policy rate and macroeconomic variables in the form of Taylor rules based on the identified structural policy reaction functions. The uncovered policy rules provide richer structural information about the dynamic nature of monetary policy than the conventional Taylor rule, especially about the policymakers' style of responsiveness to movements in inflation and output growth induced by structural shocks. Our analysis also enables us to evaluate the effectiveness of monetary policy via counterfactual studies.

This paper provides new findings on the style of monetary policy in responding to structural shocks. First, the policy rate increases over time more strongly in response to demand-induced movements in inflation and output growth than to supply-induced ones, consistent with the wisdom from the optimal monetary policy literature. Second, for the pre-1979 period, short-run monetary policy involved aggressive tightening with a bang-bang control, especially upon inflation pressure. For the post-1979 period, however, monetary policy was only mildly responsive to inflation and output growth in the initial periods, but it became increasingly aggressive over time - suggesting a pattern of optimal control with a precautionary or learning mechanism. Third, contemporaneous policy actions increased output and inflation volatilities substantially during the pre-1979 period, whereas their impact on volatilities was small or even negative during the later period.

Given that the conventional Taylor rule is a distilled representation of an amalgam of complex endogenous policy responses, the use of such a rule in adjusting the policy rate to output and inflation, irrespective of the source of shocks, is suboptimal. The structural dissection of the Taylor rule should help improve our understanding of policy reactions in the face of different and large shocks. Global financial crises in recent years and their implications for macroeconomic stability call for prudent policy reactions by policymakers in response to shocks from different sources (such as energy and commodity price shocks versus financial shocks). In future research, it will be important to examine how a policy rule could be applied responsibly to structural shocks including large financial shocks. It will also be interesting to extend the new Taylor rules to other countries including emerging markets. 


\section{References}

Barro, Robert J., 1997, Macroeconomics, 5th Edition, The MIT Press.

Barth, Marvin and Valerie Ramey, 2001, "The Cost Channel of Monetary Transmission," NBER Macroeconomics Annual, Vol. 16, pp. 199-240.

Benigno, Pierpaolo, and Michael Woodford, 2005, "Inflation Stabilization and Welfare: The Case of a Distorted Steady State," Journal of the European Economic Association, Vol. 3 (December), pp. 1185-1236.

Bernanke, Ben, Jean Boivin, and Piotr Eliasz, 2005, "Measuring the Effects of Monetary Policy: A Factor-augmented Vector Autoregressive (FAVAR) Approach," Quarterly Journal of Economics, Vol. 120 (January), pp. 387-422.

Bernanke, Ben S., Mark Gertler, and Mark Watson, 2004, "Reply: Oil Shocks and Aggregate Macroeconomic Behavior: The Role of Monetary Policy," Journal of Money, Credit, and Banking, Vol. 36, pp. 287-91.

Bernanke, Ben S., Mark Gertler, and Mark Watson, 1997, "Systematic Monetary Policy and the Effects of Oil Price Shocks,” Brookings Papers on Economic Activity, n1, pp. 91-142.

Blanchard, Olivier Jean, and Danny Quah, 1989, “The Dynamic Effects of Aggregate Demand and Supply Disturbances," American Economic Review, Vol. 79, pp. 655-73.

Boivin, Jean, and Marc P. Giannoni, 2006, "Has Monetary Policy Become More Effective?" Review of Economics and Statistics, Vol. 88 (August), pp. 445-62.

Canzoneri, Matthew B., Dale W. Henderson, and Kenneth S. Rogoff, 1983, "The Information Content of the Interest Rate and Optimal Monetary Policy," Quarterly Journal of Economics, Vol. 98 (November) pp. 545-66.

Cecchetti, Stephen G., Alfonso Flores-Lagunes, and Stefan Krause, 2006, "Has Monetary Policy Become More Efficient? A Cross-Country Analysis,” Economic Journal, Vol. 116 (April), pp. 408-33.

Choi, Woon Gyu, 1999, "Estimating the Discount Policy Reaction Function of the Monetary Authority," Journal of Applied Econometrics, Vol. 14 (July-August), pp. 379-401.

Choi, Woon Gyu, 2002, "Inverted Fisher Hypothesis: Inflation Forecastability and Asset Substitution," IMF Staff Papers, Vol. 49, No. 2, 2002, pp. 212-41.

Chowdhury, Ibrahim, and Andreas Schabert, 2008, "Federal Reserve Policy Viewed through a Money Supply Lens,” Journal of Monetary Economics, 2008, Vol. 55 (May), pp. 825-34. 
Christiano, Lawrence J., and Martin Eichenbaum, 1992, "Liquidity Effects and the Monetary Transmission Mechanism," American Economic Review, Vol. 82 (May), pp. 346-52.

Clarida, Richard, Jordi Galí, and Mark Gertler, 1999, “The Science of Monetary Policy: A New Keynesian Perspective.” Journal of Economic Literature, Vol. 37 (December), pp. 1661-1707.

Clarida, Richard, Jordi Galí, and Mark Gertler, 2000, "Monetary Policy Rules and Macroeconomic Stability: Evidence and Some Theory," Quarterly Journal of Economics, Vol. 115 (February), pp. 147-80.

Dotsey, Michael, and Andreas Hornstein, 2003, "Should a Monetary Policymaker Look at Money?” Journal of Monetary Economics, Vol. 40 (April), pp. 547-79.

Dotsey, Michael, and Robert G. King, 1983, "Monetary Policy Instruments and Policy Rules in a Rational Expectations Environment," Journal of Monetary Economics, Vol. 12 (September), pp. 357-82.

Favero, Carlo A., and Riccardo Rovelli, 2003, "Macroeconomic Stability and the Preferences of the Fed: A Formal Analysis, 1961-1998," Journal of Money, Credit and Banking, Vol. 35 (August), pp. 545-56.

Galí, Jordi, 1992, "How Well Does the IS-LM Model Fit Postwar U.S. Data," Quarterly Journal of Economics, Vol. 107 (May), pp. 709-38.

Giordani, Paolo, “An Alternative Explanation of the Price Puzzle,” Journal of Monetary Economics, September 2004, Vol. 51, pp. 1271-96.

Hamilton, James D., and Ana Maria Herrera, 2004, "Comment: Oil Shocks and Aggregate Macroeconomic Behavior: The Role of Monetary Policy," Journal of Money, Credit, and Banking, Vol. 36, pp. 265-86.

Ireland, Peter, 2007, "Changes in the Federal Reserve's Inflation Target: Causes and Consequences," Journal of Money, Credit, and Banking, Vol. 39 (December), pp. 1851-82.

Judd, John P., and Glenn D. Rudebusch, 1998, “Taylor's Rule and the Fed: 1970-1997,” Federal Reserve Bank of San Francisco Economic Review, n3, pp. 3-16.

Khan, Aubhik, Robert G. King, and Alexander L. Wolman, 2003, "Optimal Monetary Policy,” Review of Economic Studies, Vol. 70 (October), pp. 825-60.

King, Robert G., and Mau-Ting Lin, 2005, "Reexamining the Monetarist Critique of Interest Rate Rules,” Federal Reserve Bank of St. Louis Review, Vol. 87 (July/August), pp. 513-30.

Leeper, Eric M., Christopher A. Sims, and Tao Zha, 1996, "What Does Monetary Policy Do?" Brookings Papers on Economic Activity, n2, pp. 1-63. 
Leeper, Eric M., and Tao Zha, 2003, "Modest Policy Interventions," Journal of Monetary Economics, Vol. 50 (November), pp. 1673-1700.

Lubik, Thomas A., and Frank Schorfheide, 2004, “Testing for Indeterminacy: An Application to U.S. Monetary Policy," American Economic Review, Vol. 94 (March), pp. 190-217.

Lucas, Robert E. Jr., 1976, "Econometric Policy Evaluation: A Critique," Carnegie-Rochester Conference Series on Public Policy, Vol. 1, pp. 19-46.

Poole, William, 1970, "Optimal Choice of Monetary Policy Instruments in a Simple Stochastic Macro Model," Quarterly Journal of Economics, Vol. 84 (May), pp. 197-216.

Primiceri, Giorgio E., 2006, “Why Inflation Rose and Fell: Policymakers' Beliefs and US Postwar Stabilization Policy," Quarterly Journal of Economics, Vol. 121 (August), pp. 867-901.

Primiceri, Giorgio E., 2005, "Time Varying Structural Vector Autoregressions and Monetary Policy," Review of Economic Studies, Vol. 72 (July), pp. 821-52.

Rudebusch, Glenn D., 2002, “Term Structure Evidence on Interest Rate Smoothing and Monetary Policy Inertia,” Journal of Monetary Economics, Vol. 49 (September), pp. 1161-87.

Rudebusch, Glenn D., 1995, "Federal Reserve Interest Rate Targeting, Rational Expectations, and the Term Structure," Journal of Monetary Economics, Vol. 35 (April), pp. 245-74.

Sims, Christopher A., 1982, "Policy Analysis with Econometric Models," Brookings Papers on Economic Activity 1, pp. 107-52.

Sims, Christopher A., 1980, "Macroeconomics and Reality,” Econometrica, Vol. 48 (January), pp. $1-48$.

Sims, Christopher A., and Tao Zha, 1998, “Does Monetary Policy Generate Recessions?” Mimeo, Federal Reserve Bank of Atlanta.

Schmitt-Grohe, Stephanie, and Martin Uribe, 2007, "Optimal Simple and Implementable Monetary and Fiscal Rules,” Journal of Monetary Economics, Vol. 54 (September), pp. 1702-25.

Schmitt-Grohe, Stephanie, and Martin Uribe, 2004, "Optimal Fiscal and Monetary Policy under Sticky Prices," Journal of Economic Theory, Vol. 114 (February), pp. 198-230.

Söderlind, Paul, Ulf Söderström, and Anders Vredin, 2005, Macroeconomic Dynamics, Vol. 9 (June), pp. 412-28.

Stock, James H., and Mark W. Watson, 2002, "Has the Business Cycle Changed and Why?" NBER Macroeconomics Annual, pp. 159-218.

Taylor, John B., 1993, "Discretion versus Policy Rules in Practice," Carnegie-Rochester Conference Series on Public Policy, Vol. 39 (December), pp. 195-214. 